Review

\title{
Antitumor Compounds from Marine Actinomycetes
}

\author{
Carlos Olano, Carmen Méndez and José A. Salas *
}

Departamento de Biología Funcional e Instituto Universitario de Oncología del Principado de Asturias (I.U.O.P.A), Universidad de Oviedo, 33006 Oviedo, Spain; E-Mails: olanocarlos@uniovi.es (C.O.); cmendezf@uniovi.es (C.M.)

* Author to whom correspondence should be addressed; E-Mail: jasalas@uniovi.es; Tel.: +34-985103652; Fax: +34-985-103652

Received: 25 May 2009; in revised form: 8 June 2009 / Accepted: 11 June 2009 /

Published: 11 June 2009

\begin{abstract}
Chemotherapy is one of the main treatments used to combat cancer. A great number of antitumor compounds are natural products or their derivatives, mainly produced by microorganisms. In particular, actinomycetes are the producers of a large number of natural products with different biological activities, including antitumor properties. These antitumor compounds belong to several structural classes such as anthracyclines, enediynes, indolocarbazoles, isoprenoides, macrolides, non-ribosomal peptides and others, and they exert antitumor activity by inducing apoptosis through DNA cleavage mediated by topoisomerase I or II inhibition, mitochondria permeabilization, inhibition of key enzymes involved in signal transduction like proteases, or cellular metabolism and in some cases by inhibiting tumor-induced angiogenesis. Marine organisms have attracted special attention in the last years for their ability to produce interesting pharmacological lead compounds.
\end{abstract}

Keywords: anthracycline; indolocarbazole; macrolide; non-ribosomal peptide synthetase; polyketide synthase 


\section{Introduction}

Actinomycetes, characterized by a complex life cycle, are filamentous Gram-positive bacteria belonging to the phylum Actinobateria that represents one of the largest taxonomic units among the 18 major lineages currently recognized within the domain Bacteria [1]. Actinobacteria are widely distributed in terrestrial and aquatic ecosystems, especially in soil, where they play a crucial role in the recycling of refractory biomaterials by decomposing complex mixtures of polymers in dead plant, animal and fungal materials. They are important in soil biodegradation and humus formation by the recycling of nutrients associated with recalcitrant polymers such as keratin, lignocelluloses and chitin [2-4] and produce several volatile substances like geosmin responsible of the characteristic "wet earth odor" [5]. They also exhibit diverse physiological and metabolic properties, such as the production of extracellular enzymes $[3,6]$.

Around 23,000 bioactive secondary metabolites produced by microorganisms have been reported and over 10,000 of these compounds are produced by actinomycetes, representing $45 \%$ of all bioactive microbial metabolites discovered [7]. Among actinomycetes, around 7,600 compounds are produced by Streptomyces species [7]. Many of these secondary metabolites are potent antibiotics, which has made streptomycetes the primary antibiotic-producing organisms exploited by the pharmaceutical industry [7]. Members of this group are producers, in addition, of clinically useful antitumor drugs such as anthracyclines (aclarubicin, daunomycin and doxorubicin), peptides (bleomycin and actinomycin D), aureolic acids (mithramycin), enediynes (neocarzinostatin), antimetabolites (pentostatin), carzinophilin, mitomycins and others [8,9]. However, the search for novel drugs is still a priority goal for cancer therapy, due to the rapid development of resistance to multiple chemotherapeutic drugs. In addition, the high toxicity usually associated with cancer chemotherapy drugs and their undesirable side effects increase the demand for novel antitumor drugs active against untreatable tumors, with fewer side effects and/or with greater therapeutic efficiency [10].

Progress has been made recently on drug discovery from actinomycetes by using high-throughput screening and fermentation, mining genomes for cryptic pathways, and combinatorial biosynthesis to generate new secondary metabolites related to existing pharmacophores [11]. In addition, in the last years the isolation of marine actinomycetes has been a great source of new compounds and their isolation all around the globe, from shallow costal sediments to the deepest sediments from the Mariana Trench, demonstrates that actinomycetes are ubiquitous in marine sediments, but at lower numbers than in soil [12-24]. The oceans are highly complex environments and house a diverse assemblage of microbes that occur in environments with extreme variations in pressure, salinity, and temperature. The oceans cover around $70 \%$ of the Earth's surface and present themselves as an unexplored area of opportunity. Marine microorganisms encompass a complex and diverse assemblage of microscopic life forms, of which it is estimated that only $1 \%$ has been cultured or identified [25]. In addition, marine actinomycetes have been found in symbiosis with different marine invertebrates, especially sponges [26,27]. Marine actinomycetes have attracted great attention since they have developed unique metabolic and physiological capabilities that not only ensure survival in extreme habitats, but also offer the potential to produce compounds with antitumor and other interesting pharmacological activities that would not be observed in terrestrial microorganisms [28-32], perhaps because of their close relationships with marine eukaryotic organisms including mammals $[11,26]$. 
However, one of the main problems associated with marine actinomycetes is the difficulty often found for their culture, due to specific requirements like sea salt, since in some cases these microorganisms are obligate halophiles [33]. There are a number of reports on techniques and approaches for accessing previously uncultured soil actinomycetes and the biosynthesis gene clusters they harbor $[34,35]$. In the case of marine actinomycetes these studies are only beginning, but there have already been several attempts to optimize their isolation and growth from several sources [26,36,37] as well as the improvement of the fermentation process for the production of specific compounds [33,38,39] and the development of tools to facilitate the genetic manipulation of the isolated biosynthesis gene clusters $[40,41]$.

In this review we focus on novel antitumor compounds identified from marine actinomycetes and classified them in terms of their chemical structure (Table 1), covering the literature until February 2009.

Table 1. Antitumor compounds produced by marine actinomycetes.

\begin{tabular}{|c|c|c|c|}
\hline Compound & Structural type & Organism & Ref. \\
\hline \multirow[t]{2}{*}{ 1-hydroxy-1-norresistomycin } & \multirow[t]{2}{*}{ Polyketide } & Streptomyces chinaensis $\mathrm{AUBN}_{1} / 7$ & 87 \\
\hline & & Streptomyces sp. B8005 & 88 \\
\hline 1,6-phenazinediol & Phenazine & Actinomadura sp. M048 & 116 \\
\hline $\begin{array}{l}\text { 1,8-dihydroxy-2-ethyl-3- } \\
\text { methylanthraquinone }\end{array}$ & Polyketide & Streptomyces sp. FX-58 & 86 \\
\hline 3,6-disubstituted indoles & Indole & Streptomyces sp. BL-49-58-005 & 167 \\
\hline $\begin{array}{l}\text { 4a,8a-dimethyl-6-(2-methyl- } \\
\text { propenyloxy)- }\end{array}$ & Isoprenoid & Actinobacterium sp. MS1/7 & 143 \\
\hline \multicolumn{4}{|l|}{$3,4,4 \mathrm{a}, 4 \mathrm{~b}, 5,6,8 \mathrm{a}, 9$-octahydro- } \\
\hline \multicolumn{4}{|l|}{ 1H-phenanthren-2-one } \\
\hline Actinofuranones & Polyketide & Streptomyces sp. CNQ766 & 65 \\
\hline Altemicidin & Isoprenoid & Streptomyces sioyaensis SA-1758 & 135,136 \\
\hline Ammosamides & Pyrroloiminoquinone & Streptomyces sp. CNR-698 & 162 \\
\hline Arcyriaflavin A & Indolocarbazole & Actinomycete sp. $\mathrm{Z}_{2} 039-2$ & 153 \\
\hline Arenamides & Non-ribosomal peptide & Salinispora arenicola CNT-088 & 117 \\
\hline Arenicolides & Polyketide & Salinispora arenicola CNR-005 & 44 \\
\hline Aureoverticillactam & Polyketide & Streptomyces aureoverticillatus NPS001583 & 53 \\
\hline Bohemamines & Pyrrolizidine & Streptomyces sp. CNQ-583 & 163 \\
\hline Butenolides & Butenolide & Streptoverticillium luteoverticillatum 11014 & 173 \\
\hline Caboxamycin & Benzoxazole & Streptomyces sp. NTK 937 & 172 \\
\hline Chalcomycin & Polyketide & Streptomyces sp. M491 & 49 \\
\hline \multirow[t]{2}{*}{ Chalcomycin B } & Polyketide & Streptomyces sp. B7064 & 50 \\
\hline & & Streptomyces sp. M491 & 49 \\
\hline Chandrananimycins & Phenoxazin-3-one & Actinomadura sp. M048 & 179 \\
\hline Chartreusin & Polyketide & Streptomyces sp. QD518 & 75 \\
\hline Chinikomycins & Polyketide & Streptomyces sp. M045 & 57 \\
\hline Chlorinated dihydroquinones & Isoprenoid & Actinomycete isolate CNQ-525 & 141 \\
\hline Cyanosporasides & Polyketide & Salinispora pacifica CNS103 & 66 \\
\hline Daryamides & Polyketide & Streptomyces sp. CNQ-085 & 58 \\
\hline Echinosporins & Acetal-lactone & Streptomyces albogriseolus A2002 & 180 \\
\hline Fridamycin D & Polyketide & Streptomyces sp. B6921 & 80 \\
\hline
\end{tabular}


Table 1. Cont.

\begin{tabular}{|c|c|c|c|}
\hline Griseorhodin A & Polyketide & Streptomyces sp. JP95 & 100,103 \\
\hline Gutingimycin & Polyketide & Streptomyces sp. B8652 & 84 \\
\hline Himalomycins & Polyketide & Streptomyces sp. B6921 & 80 \\
\hline IB-0028 & Polyketide & Actinomadura sp. BL-42-PO13-046 & 98,99 \\
\hline IB-96212 & Polyketide & Micromonospora sp. L-25-ES25-008 & 47,48 \\
\hline Iodinin & Phenazine & Actinomadura sp. M048 & 179 \\
\hline $\mathrm{K} 252 \mathrm{c}$ & Indolocarbazole & Actinomycete strain $\mathrm{Z}_{2} 039-2$ & 153 \\
\hline Komodoquinones & Polyketide & Streptomyces sp. KS3 & 73,74 \\
\hline Lajollamycin & $\begin{array}{l}\text { Polyketide/non-ribosomal } \\
\text { peptide }\end{array}$ & Streptomyces nodosus NPS007994 & 132 \\
\hline Lucentamycins & Non-ribosomal peptide & Nocardiopsis lucentensis CNR-712 & 110 \\
\hline Lynamycins & Indolocarbazole & Marinispora sp. NPS12745 & 155 \\
\hline Manumycin A & Polyketide & Streptomyces sp. M045 & 57 \\
\hline Marinomycins & Polyketide & Marinispora sp. CNQ-140 & 54 \\
\hline Marinones & Isoprenoid & Actinomycete isolate $\mathrm{CNH}-099$ & $137-139$ \\
\hline Marineosins & Polypyrrole & Streptomyces sp. CNQ-617 & 156 \\
\hline Marmycins & Polyketide & Streptomyces sp. CNH990 & 94 \\
\hline Mechercharmycins & Non-ribosomal peptide & Thermoactinomyces sp. YM3-251 & 111 \\
\hline Metacycloprodigiosin & Prodigiosin & Saccharopolyspora sp. nov. & 157 \\
\hline Nonactin & Polyketide & Streptomyces sp. KORDI-3238 & 70 \\
\hline Pacificanones & Polyketide & Salinispora pacifica CNS-237 & 63 \\
\hline Parimycin & Polyketide & Streptomyces sp. B8652 & 82 \\
\hline Piericidins & Polyketide & Streptomyces sp. YM14-060 & 67,69 \\
\hline Piperazimycins & Non-ribosomal peptide & Streptomyces sp. CNQ-593 & 120 \\
\hline \multirow[t]{2}{*}{ Proximicins } & Non-ribosomal peptide & Verrucosispora sp. MG-37 & 107,109 \\
\hline & & Verrucosispora maris AB-18-032 & 108,109 \\
\hline Questiomycins & Phenoxazin-3-one & Actinomadura sp. M048 & 179 \\
\hline Rabelomycin & Polyketide & Streptomyces sp. B6921 & 80 \\
\hline \multirow[t]{2}{*}{ Resitoflavine } & Polyketide & Streptomyces chinaensis $\mathrm{AUBN}_{1} / 7$ & 87,93 \\
\hline & & Streptomyces sp. B8005 & 88 \\
\hline \multirow[t]{2}{*}{ Resistomycin } & Polyketide & Streptomyces sp. B8005 & 88 \\
\hline & & Streptomyces sp. B4842 & 88 \\
\hline Saliniketals & Polyketide & Salinispora arenicola CNR-005 & 45 \\
\hline Salinipyrones & Polyketide & Salinispora pacifica CNS-237 & 63 \\
\hline \multirow[t]{5}{*}{ Salinosporamides } & Polyketide/non-ribosomal & Salinispora tropica CNB-392 & 64,121 \\
\hline & peptide & Salinispora tropica CNB-440 & 126 \\
\hline & & Salinispora tropica CNB-476 & 122,131 \\
\hline & & Salinispora tropica NPS000456 & 125,131 \\
\hline & & & 128 \\
\hline Sporolides & Polyketide & Salinispora tropica CNB-392 & 64 \\
\hline SS-228 Y & Polyketide & Chainia sp. SS-228 & 95,97 \\
\hline \multirow[t]{3}{*}{ Staurosporins } & Indolocarbazole & Streptomyces sp. KS3 & 74 \\
\hline & & Micromonospora sp. L-31-CLCO-002 & 151 \\
\hline & & Streptomyces sp. QD518 & 75 \\
\hline Streptochlorin & Indole & Streptomyces sp. 04DH110 & $168-171$ \\
\hline Streptokordin & Methylpyridine & Streptomyces sp. KORDI-3238. & 70 \\
\hline Streptopyrrolidine & Tetrahydropyrrole & Streptomyces sp. KORDI-3973 & 161 \\
\hline Tetracenomycin D & Polyketide & Streptomyces sp. B8005 & 88 \\
\hline Thiocoraline & Non-ribosomal peptide & Micromonospora sp. L-13-ACM2-092 & 112,113 \\
\hline
\end{tabular}


Table 1. Cont.

\begin{tabular}{lllc}
\hline T-Muurolol & Isoprenoid & Streptomyces sp. M491 & 49,140 \\
Trioxacarcins & Polyketide & Streptomyces sp. isolate B8652 & 83 \\
Undecylprodigiosin & Prodigiosin & Saccharopolyspora sp. nov. & 157 \\
ZHD-0501 & Indolocarbazole & Actinomadura sp. 007 & 152 \\
\hline
\end{tabular}

\section{Polyketides}

Polyketides are a large family of natural products produced by step-wise decarboxylative Claisentype condensation of acyl-CoA precursors, reactions catalyzed by polyketide synthases (PKSs). The carbon skeleton of polyketides may be further reduced and modified based on the programming encoded by different domains present in PKSs with ketoreductase, dehydratase and enoylreductase activities. Three types of PKSs are known to date: type I PKSs are multifunctional enzymes organized into modules, type II PKSs are multienzyme complexes carrying out a single set of activities and type III PKSs, also known as chalcone synthase-like PKSs, are iteratively acting condensing enzymes $[42,43]$.

A high number of type I polyketide derived compounds with antitumor activity have been isolated from marine actinomycetes. Such is the case of arenicolides (Figure 1), 26-membered polyunsaturated macrolactones, produced by the obligate marine actinomycete Salinispora arenicola strain CNR-005 isolated from a marine sediment sample collected at a depth of $20 \mathrm{~m}$ from the coastal water around the island of Guam.

In particular, arenicolide A was found to exhibit moderate cytotoxicity toward the human colon adenocarcinoma cell line $\mathrm{HCT}-116$ with an $\mathrm{IC}_{50}$ of $30 \mu \mathrm{g} / \mathrm{mL}$ [44]. Two bicyclic polyketides, saliniketal A and B (Figure 1), were also isolated from the same strain of S. arenicola. Using cultures of human bladder carcinoma T24 cells in conjunction with terephthalic acid, a potent tumor promoter that induces ornithine decarboxylase (ODC), saliniketals were found to inhibit ODC induction with $\mathrm{IC}_{50}$ values of 1.95 and $7.83 \mu \mathrm{g} / \mathrm{mL}$, respectively [45]. ODC, an important target for the chemoprevention of cancer, is a directed transcriptional target of the oncogene myc and is overexpressed in various tumor cells [46].

Several macrolactones have been reported in addition to the arenicolides (Figure 1). IB-96212, a 26-membered macrolide that contains a spiroketal lactone structure, is produced by Micromonospora sp. L-25-ES25-008 isolated from a sponge collected at the Indian Ocean near the coast of Mozambique [47]. This compound showed cytotoxic activity against mouse leukemia P-388 and human lung nonsmall cell A-549, colon adenocarcinoma HT-29 and melanoma MEL-28 cell lines. The activity against P-388 cell line was four orders of magnitude higher than the activity against A-549, HT-29 and MEL28 cell lines [48]. Chalcomycin, a 16-membered macrolide, is produced by Streptomyces sp. M491 isolated from the Qingdao coast (China) [49]. In addition, chalcomycin and the related compound chalcomycin B have been isolated from Streptomyces strain B7064 found in mangrove sediments in Hawaii [50]. Chalcomycin has been found to inhibit protein synthesis in HeLa human cervix carcinoma cell line [51]. The biosynthesis gene cluster of this compound was isolated and characterized from $S$. bikiniensis [52]. Aureoverticillactam is a 22-membered macrocyclic lactam produced by $S$. aureo-verticillatus NPS001583 isolated from marine sediments. Aureoverticillactam 
was found to possess moderate growth inhibitory activity against human colorectal adenocarcnioma HT-29, Jurkat leukemia and mouse melanoma B16F10 cell lines [53].

Figure 1. Polyketide compounds arenicolides and saliniketals produced by S. arenicola CNR-005 and other macrolides and macrolactams.

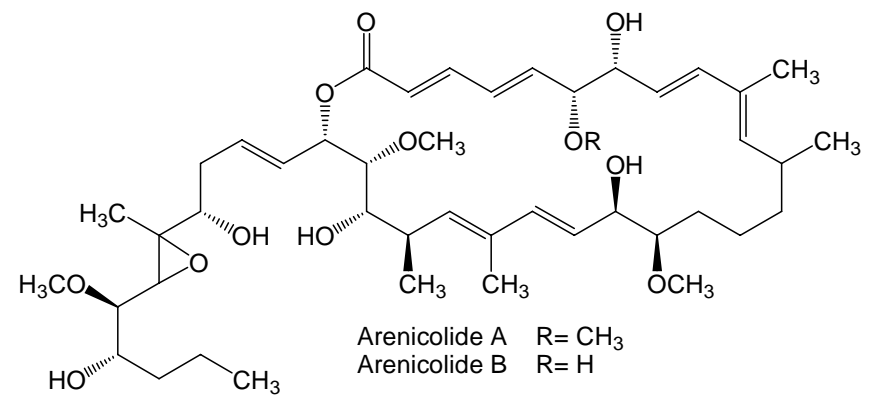

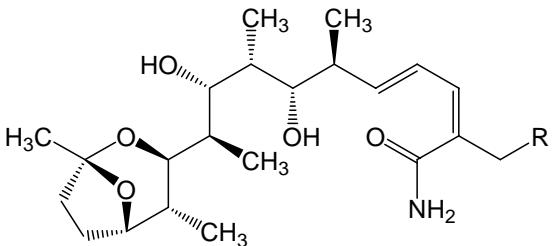

Saliniketal $A \quad R=H$ Saliniketal $B \quad \mathrm{R}=\mathrm{OH}$

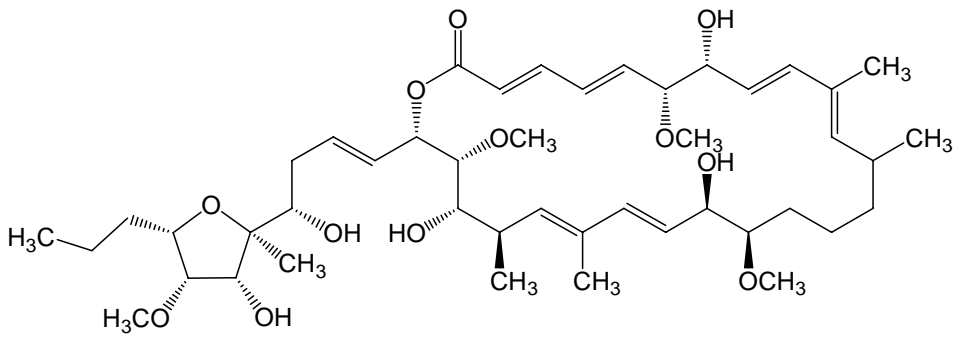
Arenicolide C

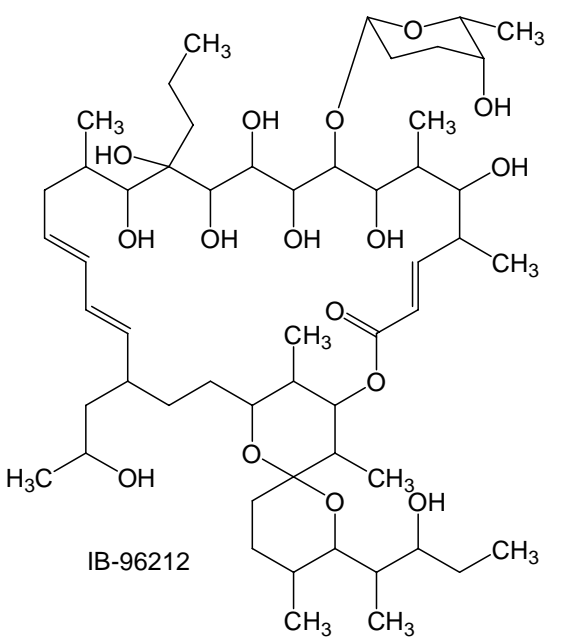

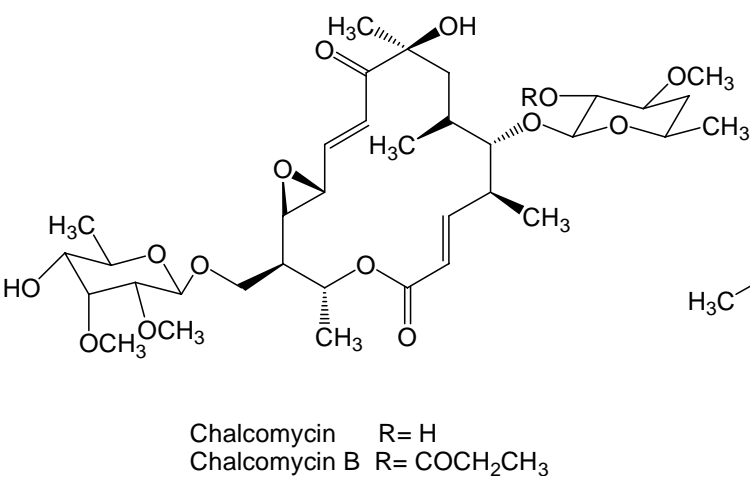<smiles>C/C=C/C=C/C=C/C(O)C(O)CC(O)/C=C\C=C\C(C)=C\C=C/CC(C/C=C/CCC)NC(=O)/C=C/C</smiles>
Aureoverticillactam

To a novel class of polyketides belong marinomycins (Figure 2), unusual macrodiolides composed of dimeric 2-hydroxy-6-alkenyl-benzoic acid lactones with conjugated tetraene-pentahydroxy polyketide chains, produced by Marinispora sp. CNQ-140 isolated from a sediment sample collected at a depth of $56 \mathrm{~m}$ offshore of La Jolla, California. These compounds inhibit cancer cell proliferation with an average $\mathrm{LC}_{50}$ of $0.2-2.7 \mu \mathrm{M}$ against the NCI's 60 cancer cell line panel. Marinomycin A showed significant tissue type selectivity being more active against human melanoma cell lines LOX IMVI, M14, SK-MEL-2, SK-MEL-5, UACC-257, and UACC-62. The most sensitive strain was melanoma SK-MEL-5 with an $\mathrm{LC}_{50}$ of $5.0 \mathrm{nM}$. Marinomycins $\mathrm{B}$ and $\mathrm{C}$ also showed potent activities with average $\mathrm{LC}_{50}$ values of 0.9 and $0.2 \mu \mathrm{M}$, respectively. The potent and selective antitumor activity of these compounds suggests a specific, but as yet unknown, mechanism of action [54]. 
The manumycins (Figure 3) constitute a class of compounds with antibiotic, cytotoxic, and other biological activities. It has been reported that manumycin A and its analogues inhibit Ras farnesyl transferase and the growth of $K i$-ras-activated murine fibrosarcoma in mice $[55,56]$. The side chains in manumycins appear to be a typical polyketide-derived moiety, differing with respect to their combinations of starter and elongation units. The central cyclohexene ring may be derived from the polyketide as in the case of manumycins or from some modified amino acid like 3-amino-5hydroxybenzoic acid. Manumycin A and chinikomycins A and B (the quinone form of chinikomycin A) were isolated from Streptomyces sp. M045 derived from sediment of Jiaozhou Bay in China. Chinikomycins A and B showed moderate antitumor activity. Chinicomycin A selectively inhibited proliferation in cell lines of mammary cancer MAXF $401 \mathrm{NL}\left(\mathrm{IC}_{50}\right.$ of $2.41 \mu \mathrm{g} / \mathrm{mL}$ ), melanoma MEXF 462NL ( $\mathrm{IC}_{50}$ of $4.15 \mu \mathrm{g} / \mathrm{mL}$ ), and renal cancer RXF 944L ( $\mathrm{IC}_{50}$ of $4.02 \mu \mathrm{g} / \mathrm{mL}$ ). Chinikomycin B showed selective antitumor activity against the mammary cancer cell line MAXF 401NL (IC50 of $3.04 \mu \mathrm{g} / \mathrm{mL}$ ) [57]. Daryamides belong also to the manumycin family of compounds. They were isolated from Streptomyces strain CNQ-085 obtained from marine sediment collected at a depth of 50 $\mathrm{m}$ off San Diego coast, California. Daryamides A to $\mathrm{C}$ and (2E,4E)-7-methylocta-2,4-dienoic acid amide were subjected to cytotoxicity evaluation against the human colon carcinoma cell line HCT-116 showing that daryamide A exhibited significantly more potent cancer cell cytotoxicity, with an $\mathrm{IC}_{50}$ of $3.15 \mu \mathrm{g} / \mathrm{mL}$, than daryamides B and C [58].

Figure 2. Structures of marinomycins.
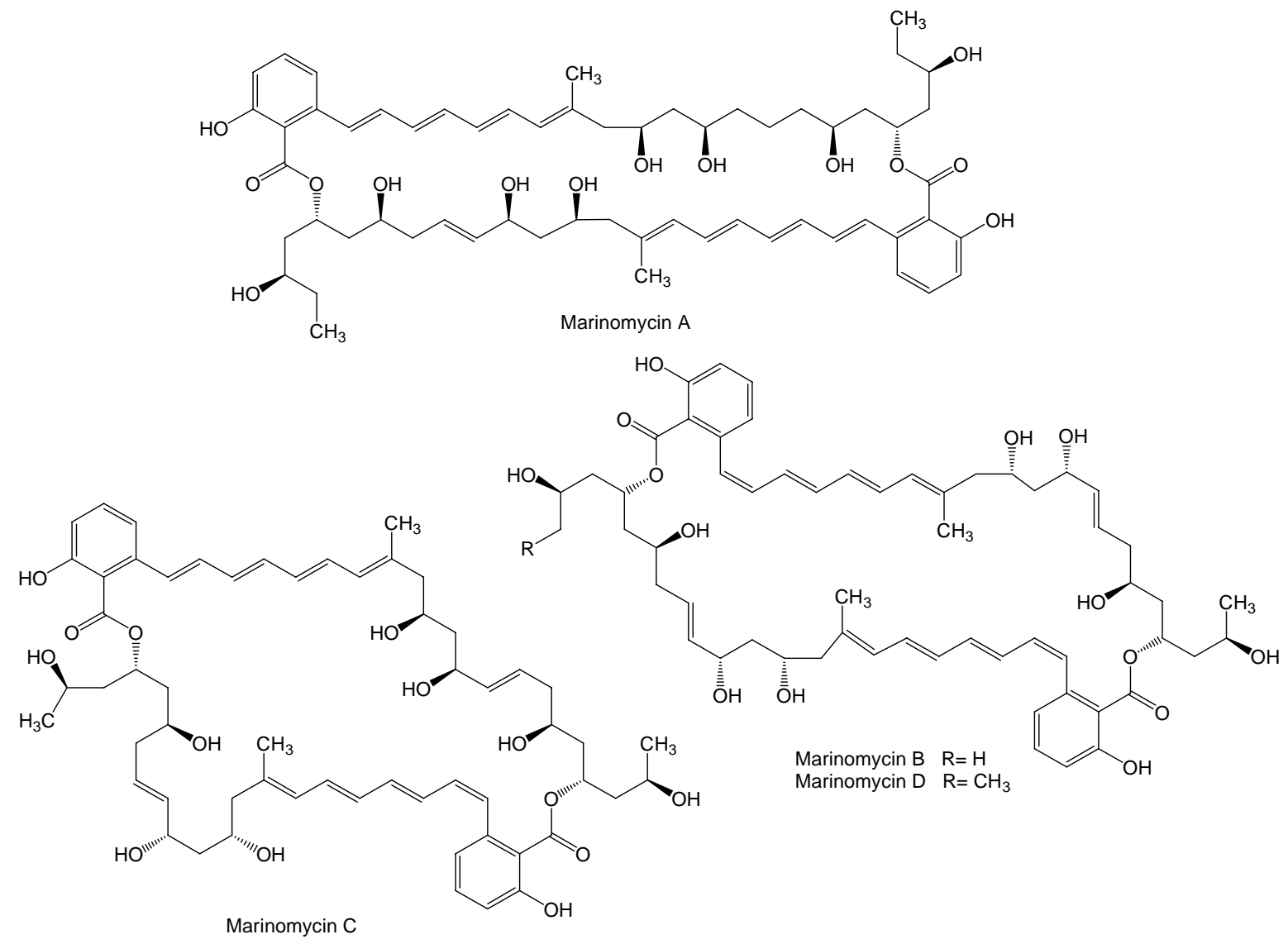
Even though it is not produced by a marine actinomycete we include in this review the antitumor compound lissoclinolide (Figure 3) isolated from the marine ascidian Lissoclinum patella [59]. This compound was originally isolated from a fungus and a soil actinomycete [60,61], which points to an actinomycete associated to L. patella as the true source of lissoclinolide. This compound, a small nonnitrogenous lactone with a putative polyketide origin probably synthesized by a type I PKS, was able to inhibit cell growth in various mammalian tumor lines at an average $\mathrm{IC}_{50}$ of $395 \mathrm{nM}$, and in particular the human colon tumor COLO 205, HCC-2998, HCT-116 and HCT-15 cell lines which resulted in a strong arrest in the $\mathrm{G}_{2} / \mathrm{M}$ phase of the cell cycle [62].

Figure 3. Structures of manumycin type compounds and lissoclinolide.
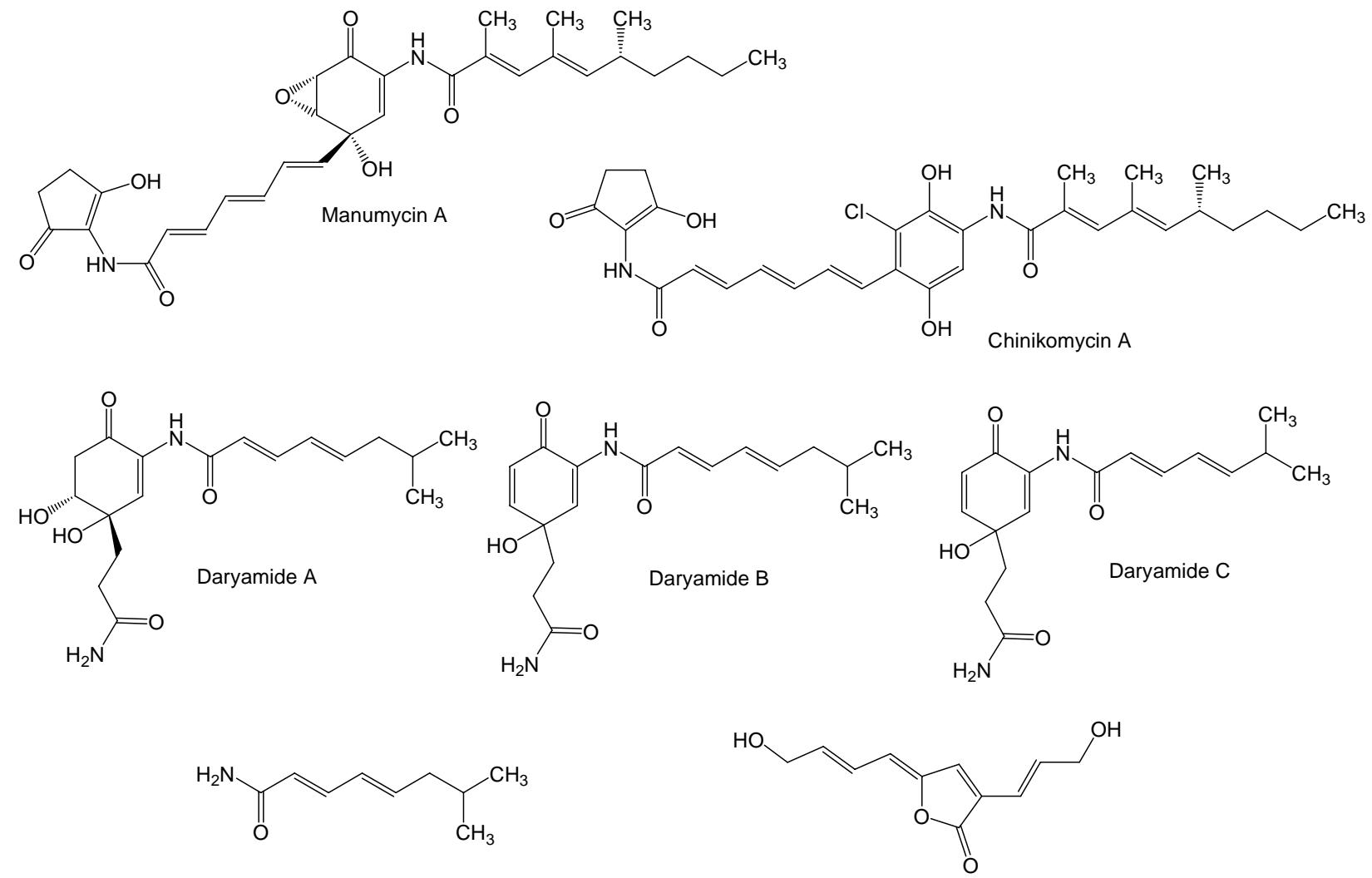

(2E,4E)-7-methylocta-2,4-dienoic acid amide

Lissoclinolide

Four new polyketides (Figure 4), salinipyrones (A and B), and pacificanones (A and B) have been isolated from cultures of the obligate marine actinomycete Salinispora pacifica CNS-237 found in a sediment sample collected in the Palau island, western Pacific Ocean. The biological activity of these compounds is currently being examined in diverse bioassays. In initial screening, the salinipyrones and the pacificanones displayed no significant activity in a cancer cytotoxicity assay using HCT-116 human colon cancer cells. In an isolated mouse splenocyte model of allergic inflammation, salinipyrone A displayed moderate inhibition of interleukin-5 production by $50 \%$ at $10 \mu \mathrm{g} / \mathrm{mL}$ without measurable human cell cytotoxicity [63]. The same apparent lack of biological activity has been found also for the polyketides sporolide A and B (Figure 4) produced by Salinispora tropica strain CNB-392 isolated from marine sediments near Chub Cay (Bahamas) [64] and actinofuranones A and B (Figure 4) isolated from culture extract of Streptomyces strain CNQ766 derived from a sediment sample 
collected from Guam [65]. Sporolides displayed no activity against human colon carcinoma HCT-116 cells and showed no significant antibiotic activity [64]. Actinofuranones showed weak in vitro cytotoxicity against mouse splenocyte T-cells and macrophages with $\mathrm{IC}_{50}$ values of $20 \mu \mathrm{g} / \mathrm{mL}$ and were inactive against human colon carcinoma HCT-116 cells [65]. Cyanosporasides A and B (Figure 4) are cyclopenta $[a]$ indene glycosides structurally related to sporolides and proposed to be cyclization products of an enediyne precursor probably synthesized by an iterative type I PKS [42]. They have been isolated from the culture broth of $S$. pacifica strain CNS103 isolated from sediments collected at a depth of $500 \mathrm{~m}$ in Palau island. To date, limited testing has shown that cyanosporaside A has weak cytotoxicity against human colon carcinoma HCT-116 (IC $\left.{ }_{50} 30 \mu \mathrm{g} / \mathrm{mL}\right)$ [66].

Figure 4. Structures of salinipyrones, pacificanones, sporolides, actinofuranones, cyanosporasides and piericidins type I polyketides and nonactin type II polyketide.<smiles>CC[C@H](O)[C@@H](C)/C=C(C)/C=C/c1oc(=O)c(C)c(O)c1C</smiles><smiles>CC[C@H](O)[C@@H](C)/C=C(C)/C=C/c1oc(=O)c(C)c(O)c1C</smiles><smiles>CC[C@H](O)[C@@H](C)/C=C(C)/C=C/[C@@]1(O)[C@@H](C)C[C@@H](CC)C(=O)[C@H]1C</smiles>

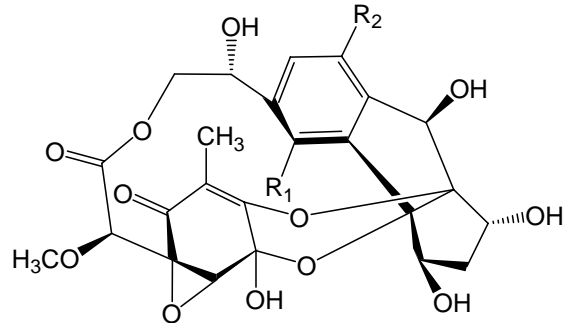

Sporolide $A \quad R_{1}=\mathrm{Cl} \quad R_{2}=H$ Sporolide $B \quad R_{1}=H \quad R_{2}=C l$<smiles>C/C=C(/C)[C@@H](O)[C@@H](C)/C=C/C=C(\C)CC[C@@H](O)CC1=C(C)C(=O)[C@](C)(O)O1</smiles>

Actinofuranone A<smiles>C/C=C(\C)[C@@H](O)[C@@H](C)/C=C/C=C(\C)CC/C=C/C1=C(C)C(=O)[C@](C)(O)O1</smiles>

Actinofuranone B<smiles>[R2]c1cc(CC=N)c([R2])c2c1C=C1C=C[C@H](O)[C@@]12OC(O)C(O)C(=O)C(C)(C)O</smiles><smiles>[R]/C(=C\C(C)=C\[C@@H](C)[C@H](O)[C@@]1(C)O[C@H]1/C(C)=C/C)C/C(C)=C/Cc1nc(OC)c(OC)c(O)c1C</smiles>

Cyanosporaside $A \quad R_{1}=C l \quad R_{2}=H$ Cyanosporaside $B \quad R_{1}=H \quad R_{2}=\mathrm{Cl}$

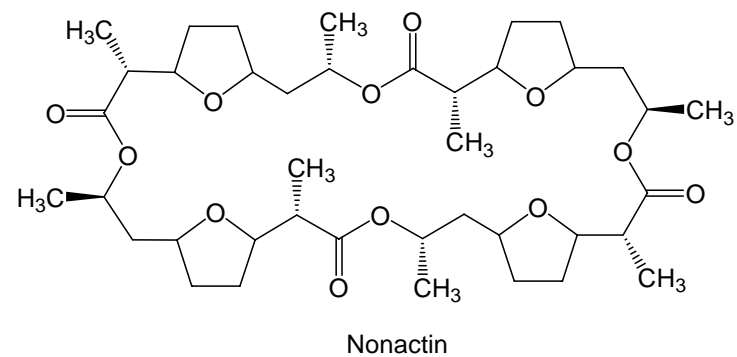


Piericidins $\mathrm{C}_{7}$ and $\mathrm{C}_{8}$ (Figure 4), probably synthesized by type I PKS, are produced by Streptomyces sp. YM14-060 isolated from an unidentified ascidian collected at Iwayama Bay, Palau Island [67]. The biological activity of piericidins was examined using rat glial cells transformed with the adenovirus E1A gene (RG-E1A-7), Neuro-2a mouse neuroblastoma cells, C6 rat glioma cells and 3Y1 rat normal fibroblast. The adenovirus E1A gene product inactivates the retinoblastoma tumor suppressor protein that plays an important role in cell-cycle and apoptosis control in mammalian cells and is inactivated during the development of a wide variety of cancers [68]. Piericidins $\mathrm{C}_{7}$ and $\mathrm{C}_{8}$ showed selective cytotoxicity against RG-E1A-7 cells ( $\mathrm{IC}_{50}$ of $1.5 \mathrm{nM}$ and $0.45 \mathrm{nM}$, respectively) and inhibited the growth of Neuro-2a cells ( $\mathrm{IC}_{50}$ of $0.83 \mathrm{nM}$ and $0.21 \mathrm{nM}$, respectively) without cytotoxic cell death. On the other hand, C6 rat glioma cells and 3Y1 rat normal fibroblast were not affected by piericidins [69].

Nonactin (Figure 4), a cyclic polyether also known as macrotetrolide, has been isolated from cultures of Streptomyces sp. KORDI-3238 isolated from a deep-sea sediment sample collected at Ayu Trough in the western Pacific Ocean [70]. The biosynthesis gene cluster of nonactin has previously been isolated and characterized from $S$. griseus DSM40695 [71] revealing that it is synthesized by a non-iteratively acting type II PKS that involves five ketosynthases and lacks the acyl carrier protein. Nonactin has been shown to be an effective inhibitor against the multidrug-resistant human erythroleukemia cell line K-562 [72].

Figure 5. Structures of several anthracyclines and anthracycline-like compounds.
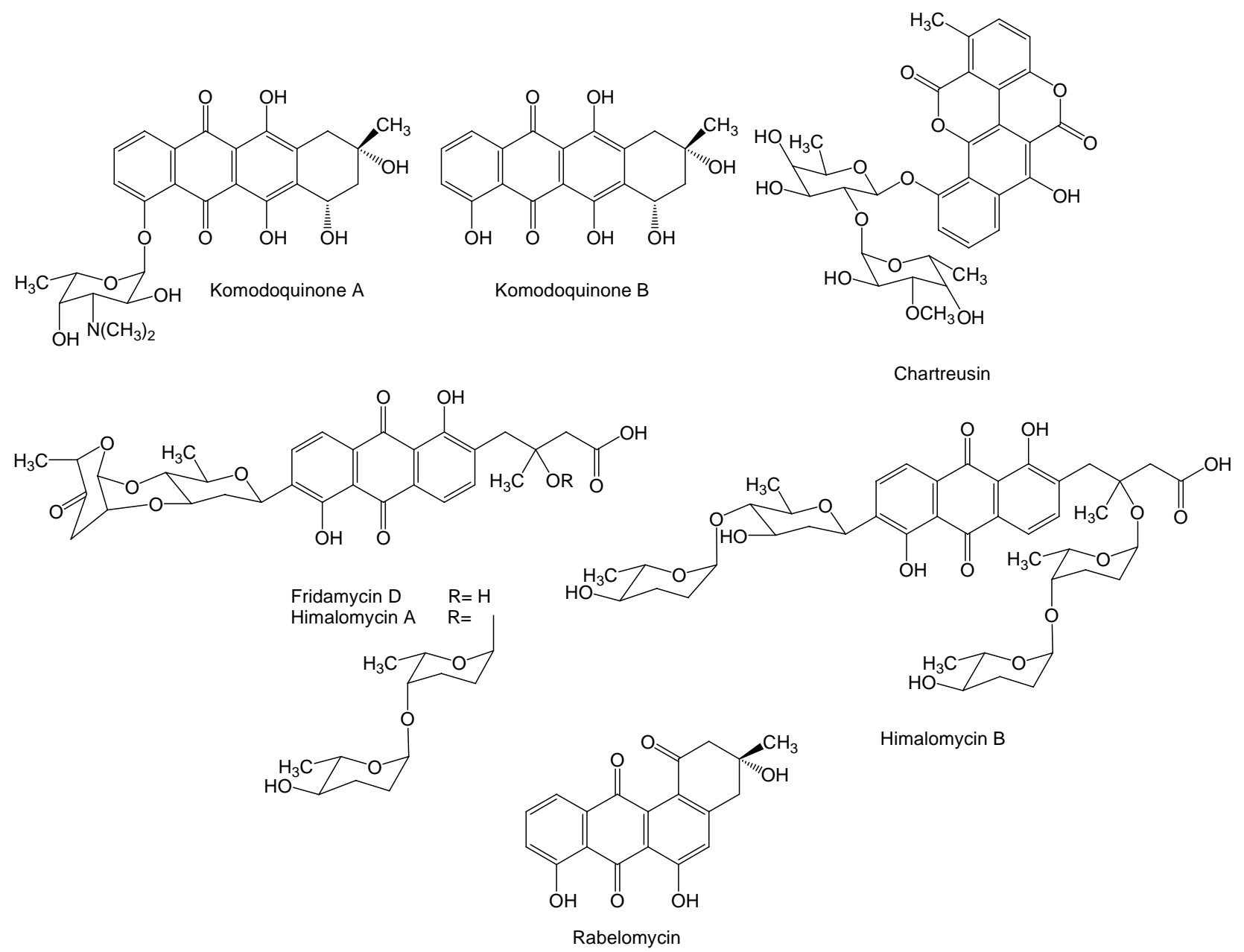
Aromatic polyketides are synthesized by type II PKS and are further divided into different structural classes such as anthracyclines, angucyclines and tetracyclines among others. To the anthracycline family of compounds belongs komodoquinone A, and its aglycone, komodoquinone B (Figure 5) produced by Streptomyces sp. KS3 isolated from marine sediments. Komodoquinone A is a unique anthracycline, in which a previously unknown amino sugar is attached to C4 instead to $\mathrm{C} 7$ as in the most known anthracyclines [73]. Komodoquinone A was found to induce neuronal cell differentiation in the neuroblastoma cell line Neuro-2a at a concentration of $1 \mu \mathrm{g} / \mathrm{mL}$, an activity not shown by doxorubicin. Treatment with komodoquinone A arrested Neuro-2a cells at the $\mathrm{G}_{1}$ phase while these treated with adriamycin were arrested at the $\mathrm{G}_{2} / \mathrm{M}$ phase. These data suggested that the amino sugar moiety attached to $\mathrm{C} 4$ might be important for neuritogenic activity of komodoquinone A, activity probably exerted by a mechanism different from the intercalation in DNA [73,74]. Another anthracycline related compound, chartreusin, has been isolated from cultures of Streptomyces sp. QD518 isolated from the Jiaozhou Bay of Quindao, China [75]. Chartreusin (Figure 5) is an aromatic glycosylated polyketide, currently in phase II clinical trials [76], that possesses an unusual bislactone synthesized through anthracycline intermediates that might undergo a series of oxidative rearrangements to generate the final bislactone structure. This particular biosynthetic process has been unraveled by the isolation of the chartreusin biosynthesis gene cluster from $S$. chartreusis [77]. Chartreusin has been shown to exert antitumor activity through binding to DNA, radical-mediated single-strand breaks and inhibition of topoisomerase II [78]. It possesses a significant chemotherapeutic activity against various tumor cell lines such as murine P388 and L1210 leukemia, and B16 melanoma cells [79]. Streptomyces sp. B6921 is the producer of several anthracycline Cglycosides such as fridamycin D, himalomycin A and B, and the angucycline rabelomycin (Figure 5). Only antibiotic activity has been reported for these compounds [80]. However, other compounds analogous to fridamycin D and himalomycin A and B such as vineomycins have been shown to exhibit antitumor activity against Sarcoma-180 solid tumor in mice [81].

Several compounds of the anthraquinone family (Figure 6), closely related to anthracyclines, are produced by Streptomyces sp. isolate B8652 derived from a sediment of the Laguna de Términos at the Gulf of México. All these compounds, parimycin, trioxacarcins and gutingimycin, showed antitumor activities at different degrees [82-84]. It has been shown that trioxacarcin A forms a stable complex with dsDNA and the cleavage of these complexes provided the natural product gutingimycin by guanine abstraction [85]. Parimycin showed activity against human tumor cell lines of stomach cancer GXF 251L, lung cancer H460, LXFA 629L, and LXFL 529L, breast cancer MCF-7 and MAXF 401NL, melanomas MEXF 462NL and MEXF 514L with $\mathrm{IC}_{70}$ values ranging from 0.9 to $6.7 \mu \mathrm{g} / \mathrm{mL}$ [82]. Trioxacarcins $A$ to $\mathrm{D}$ showed pronounced antitumor activities with mean $\mathrm{IC}_{70}$ values ranging from 0.001 to $2.161 \mu \mathrm{g} / \mathrm{mL}$ against human tumor cell lines of colon cancer HT-29, melanoma MEXF 514L, lung adenocarcinoma LXFA 526L, large cell lung cancer LXFL 529L and H-460, central nervous system SF-268, mammary cancer MCF-7, prostate cancer PC3M, and renal cancer RXF 631L. Trioxacarcin A was the most potent of all trioxacarcins, and gutingimycin was the less active with a mean $\mathrm{IC}_{70}$ value of $3.386 \mu \mathrm{g} / \mathrm{mL}$. Trioxacarcin A also proved to be very toxic in preliminary in vivo experiments in tumor bearing nude mice, being the maximum tolerated dose between 0.1 and 0.3 $\mathrm{mg} / \mathrm{kg}$. Trioxacarcins B to D showed selective antitumor activity against certain tumor cell lines [83]. Another compound from the same family, 1,8-dihydroxy-2-ethyl-3-methylanthraquinone, has been 
identified from cultures of Streptomyces sp. FX-58, which was isolated from marine plant Salicornia herbacea collected in Qingdao, Shandong province, China. This compound showed inhibitory effect against human tumor cell lines of pro-myelocytic leukemia HL-60, gastric carcinoma BGC-823 and adenocarcinoma MDA-MB-435 with $\mathrm{IC}_{50}$ of $6.83,82.2$ and $56.59 \mu \mathrm{g} / \mathrm{mL}$, respectively [86].

Tetracenomycin D and other quinone-related compounds with antitumor activity have been isolated from different marine acinomycetes (Figure 6). S. chinaensis $\mathrm{AUBN}_{1} / 7$ isolated from marine sediment samples of Bay of Bengal, India, is the producer of 1-hydroxy-1-norresistomycin and resistoflavin [87]. These compounds together with resistomycin and tetracenomycin D are produced by Streptomyces sp. B8005 isolated from sediments of the Laguna de Términos at the Gulf of México [88]. Resistomycin was isolated, in addition, from Streptomyces sp. B4842 from mud sediment of a coastal site of Mauritius, Indian Ocean [88]. Tetracenomycin D was previously showed to possess cytotoxic activity [89] and it has been isolated from $S$. glauscescens as an intermediate in the biosynthesis of tetracenomycin $\mathrm{D}$, whose biosynthesis gene cluster has been studied and used for the generation of several derived compounds [90]. Resistomycin, among other activities, has also been proposed to be a modulator of apoptosis [91]. The biosynthesis gene cluster of resistomycin has been isolated and characterized from S. resistomycificus, and, as expected, involves a type II PKS [92]. 1hydroxy-1-norresistomycin [87] and resistoflavin [93] showed cytotoxic activity against human gastric adenocarcinoma HMO2 and hepatic carcinoma HePG2 cell lines.

Figure 6. Structures of anthraquinone and quinone-related compounds.

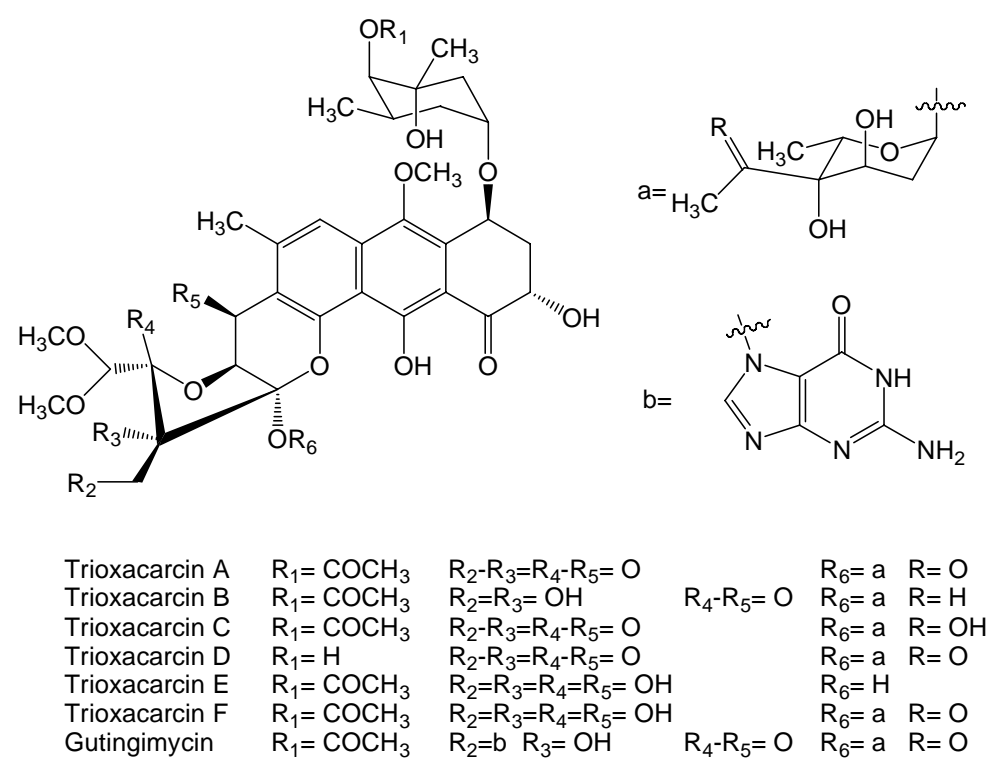<smiles>CCC(C)(O)c1cc(=O)c2c(C)cc3c(c2o1)=C(O)C1C(=O)CCC(=O)C1C=3O</smiles>

Parimycin<smiles>CCc1c(C)cc2c(c1O)C(=O)c1c(O)cccc1C2=O</smiles><smiles>[R]C1(C)C(=O)C2=C(O)C=C(O)C3=C4C=C(O)C(C(=O)c5ccc(C)cc5O)=C1C2=C43</smiles><smiles>Cc1cc(O)c2c3c1C(=O)C=C1c4c(c(O)cc(O)c4C23O)C(=O)C1(C)C</smiles><smiles>Cc1cc(O)cc2cc3c(c(O)c12)C(=O)c1c(O)cc(O)cc1C3=O</smiles> 
Two new cytotoxic quinones of the angucycline class, marmycins A and B (Figure 7) were isolated from the culture broth of Streptomyces strain CNH990 isolated from a sediment sample collected at a depth of $20 \mathrm{~m}$ at the entrance to the Sea of Cortez, $5 \mathrm{~km}$ east of Cabo San Lucas, México [94]. In cytotoxic assays using the human cell line of colon adenocarcinoma HCT-116, marmycin A showed an $\mathrm{IC}_{50}$ of $60.5 \mathrm{nM}$, almost 18 times more potent than marmycin $\mathrm{B}$, which showed an $\mathrm{IC}_{50}$ of $1.09 \mu \mathrm{M}$. Marmycin A was further evaluated for its in vitro cytotoxicity showing a mean $\mathrm{IC}_{50}$ value of $0.022 \mu \mathrm{M}$ against 12 human tumor cell lines (breast, prostate, colon, lung, leukemia). In the same assays marmycin B was significantly less potent with a mean $\mathrm{IC}_{50}$ value of $3.5 \mu \mathrm{M}$ [94]. SS-228 Y (Figure 7) is an angucycline type compound [95] produced from a species of Chainia (now Streptomyces) isolated from shallow sea mud in Sagami Bay. During SS-228 Y structural characterization this compound was found to be very labile to light and heat, being converted into the anthracycline like compound SS-228 R [95,96]. SS-228 Y inhibits growth of Ehrlich breast adenocarcinoma in mice. A prolongation of the survival period was observed in mice inoculated with Ehrlich ascites tumor when SS-228 Y was administered for 10 days at doses of more than $1.56 \mu \mathrm{g}$ per day. The acute toxicity of SS-228 Y, shown by $\mathrm{LD}_{50}$, in mice was between 1.56 and $6.25 \mathrm{mg} / \mathrm{kg}$ by intraperitoneal injection [97].

Figure 7. Structures of angucyclines and related compounds.
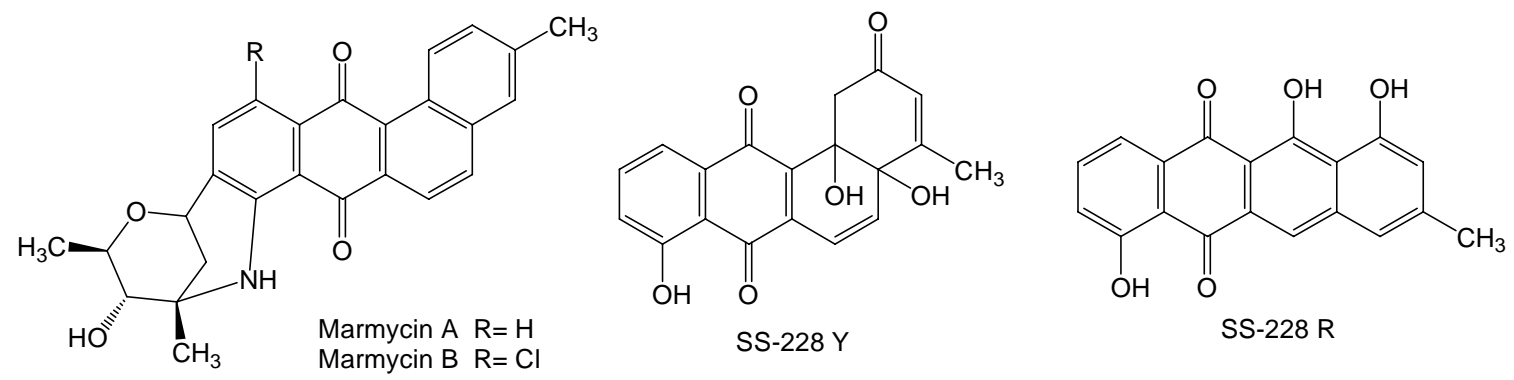

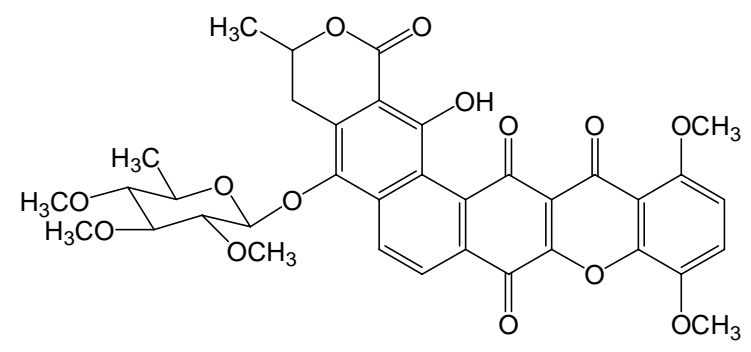

IB-00208

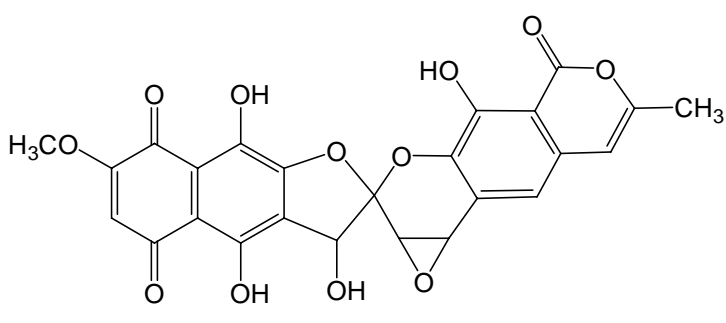

Griseorhodin A

IB-00208 (Figure 7) is a polycyclic xanthone related to angucyclines and other aromatic polyketides [98]. It was isolated from Actinomadura sp BL-42-PO13-046 collected in the northern coast of Spain associated to a polychaete. IB-00208 showed a potent cytotoxic activity against mouse leukemia P-388 and human lung non-small cell A-549, colon adenocarcinoma HT-29 and melanoma SK-MEL-28 cell lines [99]. Griseorhodin A (Figure 7) [100], that belongs to the family of pentangular polyphenols related to angucyclines and other aromatic polyketides, is an inhibitor of human telomerase [101], a ribonucleoprotein complex involved in the stabilization of telomere length in stem cells and reproductive cells and found in almost all human tumors but not in adjacent normal cells [102]. The biosynthesis gene cluster for griseorhodin A has been isolated and characterized from 
Streptomyces sp. JP95 associated with the marine ascidian Aplidium lenticulum collected at Heron Island, Queensland, Australia [103].

\section{Non-Ribosomal Peptides}

This class of natural products comprises peptides synthesized by non-ribosomal peptide synthetases (NRPS). The amino acid monomers incorporated by NRPS assembly lines are aminoacyl-AMP mixed anhydrides that follow the same chemical logic as PKSs for chain elongation and are then modified based on the program encoded by different domains present in NRPS modules, which can include epimerization, methyltransferase, reductase or oxidase activities. Quite often non-ribosomal peptides also contain some unique structural features such as heterocyclic elements and deoxysugars [104-106].

Figure 8. Structures of proximicins, lucentamycins and mechercharmycins.

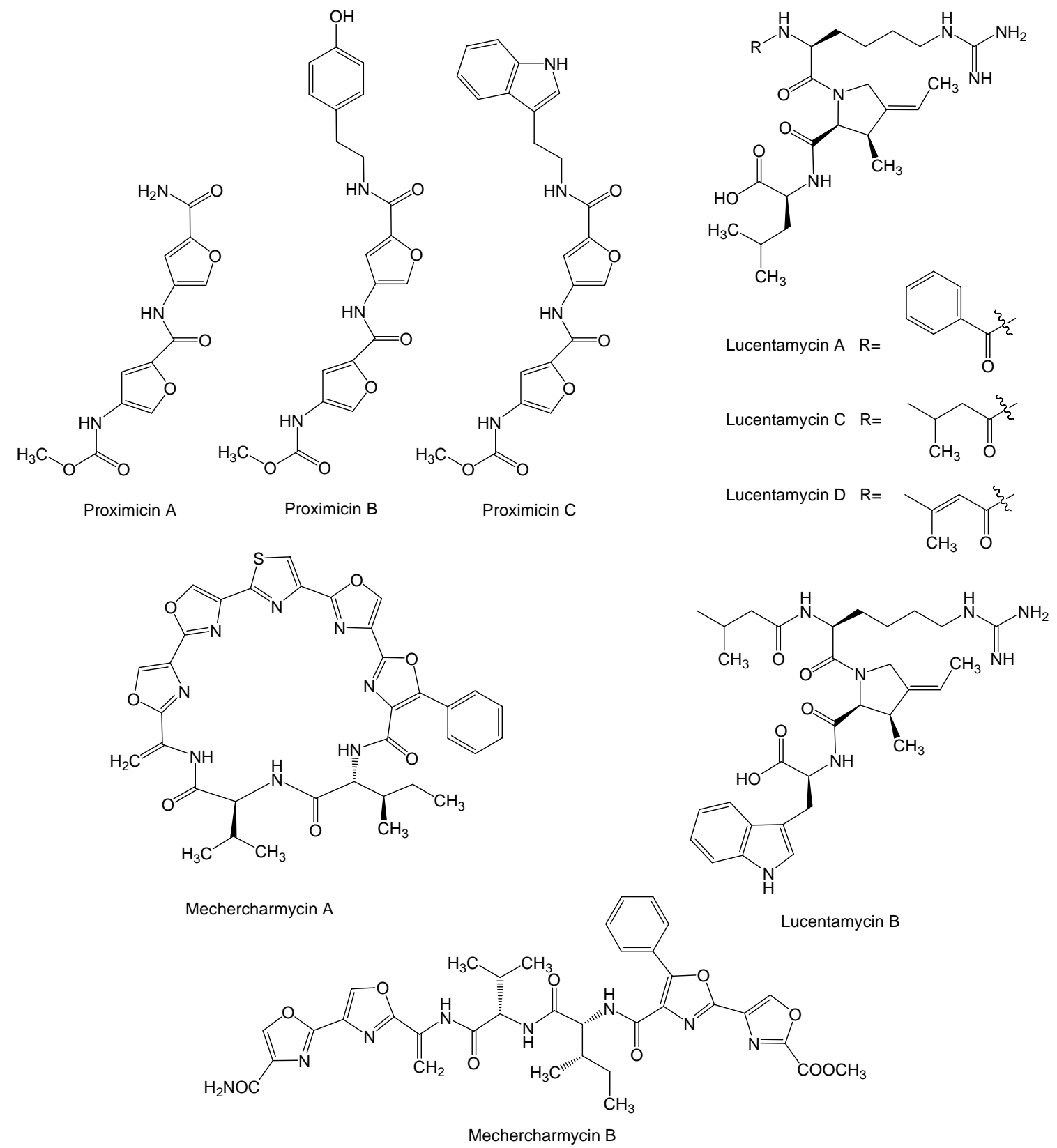


Proximicins (Figure 8) are aminofuran antibiotics, probably synthesized by a NRPS system, produced by Verrucosispora strain MG-37 and V. maris AB-18-032, and isolated from sediments collected at a depth of $250 \mathrm{~m}$ in the Raune Fjord, Norway and the Sea of Japan at a depth of $289 \mathrm{~m}$, respectively [107,108]. Proximicins A, B and C showed significant growth inhibitory activities towards human gastric adenocarcinoma $\mathrm{AGS}\left(\mathrm{GI}_{50}\right.$ of $0.6,1.5$ and $0.25 \mu \mathrm{M}$, respectively) and hepatocellular carcinoma Hep $\mathrm{G} 2\left(\mathrm{GI}_{50}\right.$ of 0.82 , 9.5 and $0.78 \mu \mathrm{M}$, respectively) [107,109], and were found to induce arrest AGS cells in $\mathrm{G}_{0} / \mathrm{G}_{1}$ and to increase the levels of p53 and p21 [109]. Lucentamycins (Figure 8), 3-methyl-4-ethylideneproline-containing peptides, are produced by Nocardiopsis lucentensis strain CNR-712 isolated from sediment collected from a shallow saline pond on the island of Little San Salvador, in the Bahamas. Lucentamycins A and B showed significant in vitro cytotoxicity against human colon carcinoma $\mathrm{HCT}-116$ cell line with $\mathrm{IC}_{50}$ values of 0.20 and 11 $\mu \mathrm{M}$, respectively. However, lucentamycins $\mathrm{C}$ and $\mathrm{D}$ were not cytotoxic in the same assay suggesting that the presence of an aromatic ring is essential for the biological activity of this class of compounds [110]. Mechercharmycins (Figure 8) are produced by Thermoactinomyces sp. YM3-251, isolated from sea mud collected at Mecherchar in the Republic of Palau (North Pacific Ocean). While mechercharmycin A showed cytotoxic activity against human lung adenocarcinoma A549 and Jurkat leukemia cells with $\mathrm{IC}_{50}$ values of $0.04 \mu \mathrm{M}$, mechercharmycin B did not show inhibitory activity in these assays even at $1 \mu \mathrm{M}$, which suggests the cyclic structure of mechercharmycin A must be essential for the antitumor activity [111].

Thiocoraline (Figure 9) is a 2-fold symmetric bicyclic non-ribosomally synthesized octathiodepsipeptide, characterized by the presence of peptide and ester bonds, produced by Micromonospora sp. L-13-ACM2-092 isolated from a soft coral collected at the Indian Ocean near the coast of Mozambique [112,113]. It shows potent antitumor activity against murine leukemia P388, human lung adenocarcinoma A549, and melanoma MEL288, being the activity against these cell lines 5-fold more potent than for human colon adenocarcinoma HT-29 cell line ( $\mathrm{IC}_{50}$ values of 0.002 vs. $0.01 \mu \mathrm{M}$, respectively) [112]. In addition, on both LOVO and SW620 human colon cancer cell lines, thiocoraline caused an arrest in $G_{1}$ phase of the cell cycle and a decrease in the rate of $S$ phase progression towards $\mathrm{G}_{2} / \mathrm{M}$ phases, due to its DNA bisintercalative properties and its DNA polymerase $\alpha$ inhibition [114]. Thiocoraline is structuraly related to other bisintercalator compounds of the quinoxaline family with potential therapeutic applications like echinomycin, inhibitor of hypoxiainducible factor-1 that controls genes important for tumor progression and metastasis that are involved in glycolysis, angiogenesis, migration, and invasion [115]. The biosynthesis gene cluster of thiocoraline has been isolated, characterized and heterologously expressed in S. lividans and S. albus [116].

Three new cyclohexadepsipeptides, arenamides (Figure 9), were isolated from the fermentation broth of a marine bacterial strain identified as $S$. arenicola CNT-088 which was obtained from a marine sediment sample collected at a depth of $20 \mathrm{~m}$ off the Great Astrolab Reef, in the Kandavu Island chain, Fiji. Arenamides A and B exhibited weak in vitro cytotoxicity against human colon carcinoma HCT-116 with $\mathrm{IC}_{50}$ values of 13.2 and $19.2 \mu \mathrm{g} / \mathrm{mL}$, respectively [117]. 
Figure 9. Structures of depsipeptides thiocoraline, arenamides and piperazimycins.
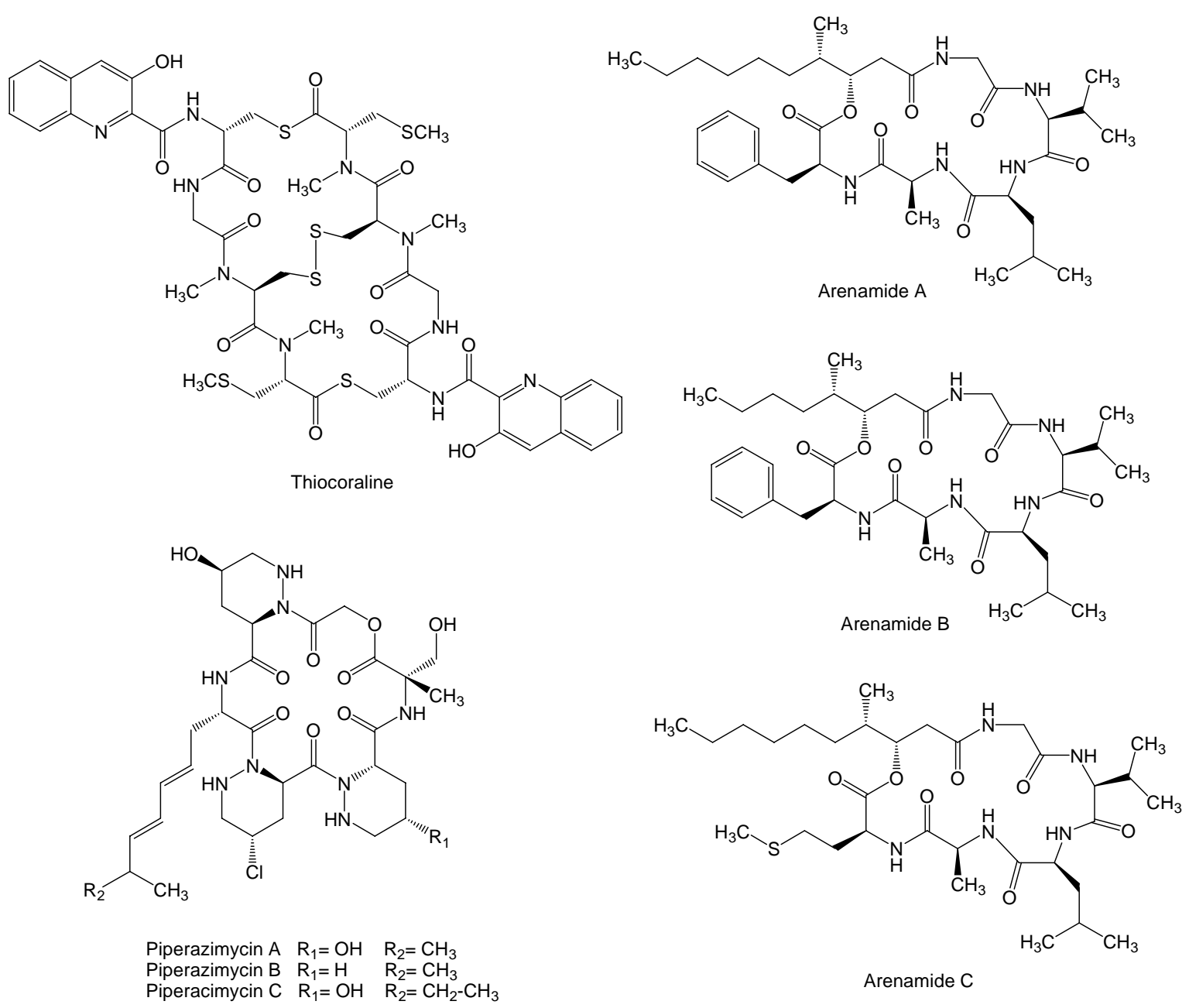

In addition, arenamides have been associated to chemoprevention of carcinogenesis by suppression of $\mathrm{NF} \kappa \mathrm{B}$ activation. $\mathrm{NF} \kappa \mathrm{B}$ regulates the expression of a number of genes, the products of which are involved in tumorigenesis [118,119]. The effect of arenamides on $\mathrm{NF} \kappa \mathrm{B}$ activity was studied with stably transfected 293/NF $\kappa$ B-Luc human embryonic kidney cells induced by treatment with tumor necrosis factor (TNF). Arenamides A and B blocked TNF-induced activation in a dose- and timedependent manner with $\mathrm{IC}_{50}$ values of 3.7 and $1.7 \mu \mathrm{M}$, respectively [117]. Piperazimycins (Figure 9) are cyclic hexadepsipeptides isolated from the fermentation broth of a Streptomyces sp. strain CNQ593, cultivated from marine sediments samples collected at a depth of approximately $20 \mathrm{~m}$ near the island of Guam. Antitumor activities for piperazimycins were initially evaluated in vitro against the human colon carcinoma HCT-116 cell line. All compounds exhibited significant cytotoxicity with an average $\mathrm{GI}_{50}$ of $76 \mathrm{ng} / \mathrm{mL}$ for each. Piperazimycin A also showed potent biological activity when evaluated against the NCI's cancer cell line panel, with mean $\mathrm{GI}_{50}$, TGI and $\mathrm{LC}_{50}$ values for all cell lines of $100 \mathrm{nM}, 300 \mathrm{nM}$ and $2 \mu \mathrm{M}$, respectively. Overall, piperazimycin A exhibited a nearly 3-fold more potent activity against solid tumors (average $\mathrm{LC}_{50}$ of $13.9 \mu \mathrm{M}$ ) than against the leukemia cell lines tested (average $\mathrm{LC}_{50}$ of $31.4 \mu \mathrm{M}$ ), being most active against the melanoma (average $\mathrm{LC}_{50}$ of 0.3 $\mu \mathrm{M}$ ), central nervous system (average $\mathrm{LC}_{50}$ of $0.4 \mu \mathrm{M}$ ), and prostate cell lines (average $\mathrm{LC}_{50}$ of 0.6 $\mu \mathrm{M})$ cancers [120]. 


\section{Mixed Polyketide-Nonribosomal Peptides}

As mentioned above, NRPSs and type I PKSs are multifunctional proteins that are organized into modules and use a similar strategy for the assembly of these two distinct classes of natural products. The combined use of NRPSs and type I PKSs allows assembling hybrid polyketide/non-ribosomal peptide compounds derived from amino acids and short-chain carboxylic acids.

The most known compound of this family is salinosporamide A (Figure 10), a highly potent inhibitor of the $20 \mathrm{~S}$ proteasome currently in phase I clinical trials for the treatment of cancer [76]. It is produced by $S$. tropica strain CNB-392 isolated from a sediment sample collected at a depth of about 1 $\mathrm{m}$ from a mangrove environment in Chub Cay, Bahamas [121] and other S. tropica strains like CNB440 and CNB-476 isolated also from Bahamas [122,123]. Salinosporamide A displayed potent in vitro cytotoxicity against human colon carcinoma HCT-116 with an $\mathrm{IC}_{50}$ value of $11 \mathrm{ng} / \mathrm{mL}$, and was shown potent and highly selective in the NCI's 60 cell line panel. The greatest potency was observed against human cell lines of non-small cell lung cancer NCI-H226, central nervous system cancer SF-539, melanoma SK-MEL-28, and breast cancer MDA-MB-435 (all with LC $_{50}$ values less than $10 \mathrm{nM}$ ). When salinosporamide A was tested against purified rabbit muscle $20 \mathrm{~S}$ proteasome, a multicatalytic complex responsible for degrading most intracellular proteins in eukaryotes, it inhibited proteasomal chymotrypsin-like proteolytic activity with an $\mathrm{IC}_{50}$ value of $1.3 \mathrm{nM}$ [121]. The $26 \mathrm{~S}$ proteasome, composed of $19 \mathrm{~S}$ and $20 \mathrm{~S}$ components, is a multicatalytic complex responsible for degrading most intracellular proteins in eukaryotes. Three distinguishable proteolytic activities are localized in the $20 \mathrm{~S}$ proteasome and are classified as chymotrypsin-, caspase-, and trypsin-like, all of them inhibited by salinosporamide A, in particular chymotrypsin and caspase-like [124]. Compounds of the same family, salinosporamides B-J (Figure 10), have been isolated together with salinosporamide A from S. tropica [125-127]. In addition, new derivatives of salinosporamide A were produced by replacement of synthetic sea salt with sodium bromide in the fermentation media of $S$. tropica that led to the production of bromosalinosporamide [128], and by derivatization of salinosporamide A and B leading to the production of several thioester analogues (designed as T in Figure 10) [127]. Salinosporamide A thioester derivatives $\mathrm{T} 1$ and $\mathrm{T} 2$ were found potent $20 \mathrm{~S}$ proteasome inhibitors with $\mathrm{IC}_{50}$ values of 3.6and 1.5-fold higher than salinosporamide A [127]. The characterization of the salinosporamide A biosynthesis gene cluster during the sequencing of $S$. tropica CNB-440 circular genome [122] has allowed the generation of several derivatives such as fluorosalinosporamide produced by mutasynthesis using a chlorinase salL mutant [129], and antiprotealide (Figure 10) produced by a combination of genetic engineering and precursor-directed biosynthesis [130]. Antiprotealide has been recently found as a natural product produced by different strains of S. tropica [131].

Lajollamycin (Figure 10) is another mixed polyketide/non-ribosomal peptide produced by $S$. nodosus strain NPS007994 isolated from marine sediments collected in Scripps Canyon, La Jolla, California. Lajollamycin was found to inhibit the growth of murine melanoma cell line B16-F10, with an $\mathrm{EC}_{50}$ of $9.6 \mu \mathrm{M}$ [132]. The biosynthesis gene cluster of oxazolomycin, a structural close relative of lajollamyin, has been isolated and characterized from $S$. albus JA3453 confirming the hybrid peptidepolyketide origin of these compounds [133]. 
Figure 10. Structures of mixed polyketide/non-ribosomal peptide compounds.<smiles>[R]C1C(=O)N[C@]2([C@@H](O)C3C=CCCC3)C(=O)O[C@]12C</smiles>

$\begin{array}{ll}\text { Salinosporamide A } & \mathrm{R}=\mathrm{CH}_{2}-\mathrm{CH}_{2}-\mathrm{Cl} \\ \text { Bromosalinosporamide } & \mathrm{R}=\mathrm{CH}_{2}-\mathrm{CH}_{2}-\mathrm{Br} \\ \text { Fluorosalinosporamide } & \mathrm{R}=\mathrm{CH}_{2}-\mathrm{CH}_{2}-\mathrm{F} \\ \text { Salinosporamide B } & \mathrm{R}=\mathrm{CH}_{2}-\mathrm{CH}_{3} \\ \text { Salinosporamide D } & \mathrm{R}=\mathrm{CH}_{3} \\ \text { Salinosporamide E } & \mathrm{R}=\mathrm{CH}_{2}-\mathrm{CH}_{2}-\mathrm{CH}_{3} \\ \text { Hexyl-salinosporamide } & \mathrm{R}=\mathrm{CH}_{2}-\left(\mathrm{CH}_{2}\right)_{4}-\mathrm{CH}_{3}\end{array}$<smiles>CC1=C(CCCl)C(=O)N2C3CC(=O)CCC3C(O)C12</smiles>

Salinosporamide C<smiles>CC1C(=O)NC2(C(O)C3C=CCCC3)C(=O)OC12C</smiles>

Salinosporamide $\mathrm{F} \quad \mathrm{R}=\mathrm{CH}_{2}-\mathrm{CH}_{2}-\mathrm{Cl} \quad$ Salinosporamide I Salinosporamide $\mathrm{G} \quad \mathrm{R}=\mathrm{CH}_{3}$ Salinosporamide $\mathrm{H} \quad \mathrm{R}=\mathrm{CH}_{2}-\mathrm{CH}_{3}$<smiles>CC[C@]12OC(=O)[C@]1([C@H](O)C1C=CCCC1)NC(=O)[C@H]2CCCl</smiles><smiles>COC(=O)CCSC(=O)C1(C(O)C2CC=CCC2)NC(=O)C(P)C1(C)O</smiles>

Salinosporamide A T2 $\mathrm{R}=\mathrm{CH}_{2}-\mathrm{CH}_{2}-\mathrm{Cl}$ Salinosporamide B T1 $\mathrm{R}=\mathrm{CH}_{2}-\mathrm{CH}_{3}$

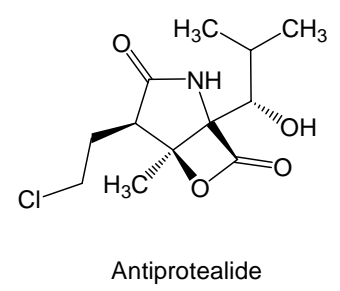

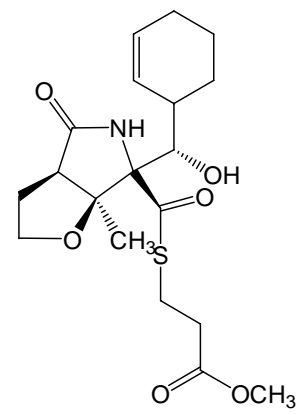

Salinosporamide A lactone T1<smiles>COC(=O)[C@H](CSC(=O)[C@@]1(C(O)C2CC=CCC2)NC(=O)[C@H]2CCO[C@H]21)NC(C)OC</smiles>

Salinosporamide A lactone T2<smiles>COC(CC(C)C(O)/C=C/C=C/CNC(=O)C(C)(C)C(O)/C(C)=C\C=C/C=C/C(C)=C(\C)[N+](=O)[O-])[C@]1(O)[C@H](C)C(=O)N(C)[C@@]12C(=O)O[C@H]2C</smiles>

\section{Isoprenoids}

Isoprenoids, similar to terpenes, are one of the largest families of natural compounds. Isoprenoids are derived from five-carbon isoprene units assembled and modified in different ways. They are classified into several groups based on the number of $\mathrm{C} 5$ units that form part of their structure: monoterpenes (C10), sesquiterpenes (C15) and diterpenes (C20) [134]. 
Altemicidin (Figure 11) with a monoterpene-alkaloid skeleton is produced by S. sioyaensis SA1758 isolated from sea mud collected at Gamo, Miyagi Prefecture, Japan [135]. This compound was found to inhibit the growth of murine lymphoid leukemia L1210 and carcinoma IMC cell lines with $\mathrm{IC}_{50}$ values of 0.84 and $0.82 \mu \mathrm{g} / \mathrm{mL}$, respectively, although it showed high acute toxicity in mice [136].

Figure 11. Structures of monoterpenes and sesquiterpenes isolated from marine actinomycetes.<smiles>CC1=CCC[C@@H](C)[C@]1(C)CC[C@@]1(C)c2c(O)cc3c(c2O[C@@H]1C)C(=O)C(C)=C(O)C3=O</smiles>

Altemicidin

Neomarinone<smiles>CC(C)=CCC[C@]1(C)OC2=C(C(=O)c3c(O)cc(O)c(Br)c3C2=O)C2CCC(C)=CC21</smiles>

Isomarinone<smiles>[R20][C@]1(C)C=C2C3=C(O[C@]2(C)CCC=C(C)C)[C@@H]1CCC3(C)C</smiles>

Hydroxydebromomarinone $\mathrm{R}=\mathrm{H}$ Methosydebromomarinone $\mathrm{R}=\mathrm{CH}_{3}$

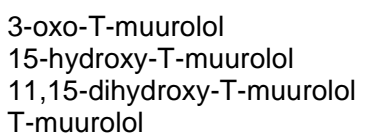

$\mathrm{R}_{1}=\mathrm{O} \quad \mathrm{R}_{2}=\mathrm{H} \quad \mathrm{R}_{3}=\mathrm{H}$

$\mathrm{R}_{1}=\mathrm{H}_{2} \mathrm{R}_{2}=\mathrm{OH} \mathrm{R}_{3}=\mathrm{H}$

$\mathrm{R}_{1}=\mathrm{H}_{2} \quad \mathrm{R}_{2}=\mathrm{OH} \mathrm{R}_{3}=\mathrm{OH}$

$\mathrm{R}_{1}=\mathrm{H}_{2} \quad \mathrm{R}_{2}=\mathrm{H} \quad \mathrm{R}_{3}=\mathrm{H}$

Marinones (Figure 11) are sesquiterpenoid naphthoquinones with a mixed polyketide-terpenoid origin [137]. Neomarinone, isomarinone, hydroxydebromomarinone and methoxydebromomarinone were produced by actinomycete isolate $\mathrm{CNH}-099$ obtained from a sediment sample taken at $1 \mathrm{~m}$ depth in Batiquitos Lagoon, North of San Diego, California. These compounds showed moderate in vitro cytotoxicity, $\mathrm{IC}_{50}$ of $8 \mu \mathrm{g} / \mathrm{mL}$, against human colon carcinoma HCT-116 cells. In addition, neomarinone generated a mean $\mathrm{IC}_{50}$ value of $10 \mu \mathrm{M}$ in the NCI's 60 cancer cell line panel $[138,139]$. T-muurolol sesquiterpernes (Figure 11) were isolated from Streptomyces strain M491 derived from sediment obtained from Jiaozhou Bay, Qingdao coast, China [49,140]. Seven out of eight sesquiterpenes of the T-muurolol family were tested for their cytotoxycity against 37 human tumor cell lines but, except for 15-hydroxy-T-muurolol which was moderately cytotoxic with an $\mathrm{IC}_{50}$ of 6.7 $\mu \mathrm{g} / \mathrm{mL}$, the other compounds including 3-oxo-T-muurolol, 11,15-dihydroxy-T-muurolol, T-muurolol and $3 \alpha$-hydroxy-T-muurolol showed no activity [140].

Several chlorinated dihydroquinones (1-5, Figure 12), with a mixed terpenoid/polyketide origin, are produced in saline culture of the actinomycete strain CNQ-525, isolated from ocean sediments collected at a depth of $152 \mathrm{~m}$ near La Jolla, California [141]. Dihydroquinones 4 and 5 were identical to the previously reported antibiotics A80915A and A80915C produced by soil actinomycete $S$. 
aculeolatus [142]. Dihydroquinones 1, 2 and 4 were found to be cytotoxic toward human colon carcinoma HCT-116 cells with $\mathrm{IC}_{50}$ of $2.4,0.97$ and $1.84 \mu \mathrm{g} / \mathrm{mL}$, respectively [141].

Actinobacterium sp. MS1/7 isolated form sediments taken at the Bay of Bengal is the producer of compound 4a,8a-dimethyl-6-(2-methyl-propenyloxy)-3,4,4a,4b,5,6,8a,9-octahydro-1H-phenanthren-2one (Figure 12), with putative isoprenoid origin. This compound was found to inhibit the growth by $54 \%$ of human leukemia HL-60 cell line at $0.05 \mu \mathrm{g} / \mathrm{mL}$ and to possess a reduced toxicity against nontumor cells since only $2.3 \%$ of murine erythrocytes and $1.6 \%$ of human erythrocytes were lysed at concentrations of $35-40 \mu \mathrm{g} / \mathrm{mL}$ [143].

Figure 12. Structures of chlorinated dihydroquinones and active compound from strain $\mathrm{MS} 1 / 7$.<smiles>[R][C@]12C[C@H](Cl)[C@@](C)(O)O[C@]1(CC1C[C@](C)(O)C[C@H](Cl)C1(C)C)C(=O)c1cc(O)c(C)c(O)c1C2=O</smiles>

Chlorinated dihydroquinone $1 \quad \mathrm{R}=\mathrm{H}$ Chlorinated dihydroquinone $5 \mathrm{R}=\mathrm{Cl}$<smiles>C=C1CC(C[C@]23OC(C)(C)[C@@H](Cl)C[C@]2(Cl)C(=O)c2c(cc(O)c(C)c2O)C3=O)C(C)(C)[C@@H](Cl)C1</smiles>

Chlorinated dihydroquinone 4<smiles>Cc1c(O)cc2c(c1O)C(=O)C1=C[C@H](Cl)[C@@](C)(O)O[C@@]1(CC1C[C@](C)(O)C[C@H](Cl)C1(C)C)C2=O</smiles>

Chlorinated dihydroquinone 2<smiles>C=C1CC(C[C@]23OC(C)(C)[C@@H](Cl)C=C2C(=O)c2c(cc(O)c(C)c2O)C3=O)C(C)(C)[C@@H](Cl)C1</smiles>

Chlorinated dihydroquinone 3<smiles>CC(C)=COC1C=CC2(C)CC=C3CC(=O)CCC3(C)C2C1</smiles>

4a,8a-dimethyl-6-(2-methyl-propenyloxy)-3,4,4a,4b,5,6,8a,9 -octahydro-1H-phenanthren-2-one

\section{Indolocarbazoles}

Most of the compounds of this family contain a characteristic indolo[2,3-a]pyrrolo[3,4-c] carbazole core derived from two units of tryptophan, with sugars attached derived from glucose and methionine. These compounds constitute a separate type of antitumor drugs with several mechanisms of action including DNA-damage targeting on topoisomerases I and II, and inhibition of protein kinases, including serine/threonine and tyrosine kinases [144]. One of the better known indolocarbazole, staurosporine (Figure 13) has been isolated from several marine actinomycetes including komodoquinones-producer Streptomyces sp. KS3 [74] after its discovery from cultures of $S$. staurosporeus AM-2282 [145]. The staurosporine biosynthesis gene cluster was identified and characterized from Streptomyces sp. TP-A0274 and S. longisporoflavus [146,147], which has led to the generation of several derivatives of indolocarbazoles staurosporine and rebeccamycin with antitumor 
activity [147-150]. Staurosporine has been isolated, in addition, together with two natural analogues, 4'- $\mathrm{N}$-methyl-5'-hydroxystaurosporine and 5'-hydroxystaurosporine (Figure 13) from Micromonospora sp. L-31-CLCO-002 obtained from a homogenate of the sponge Clathrina coriacea collected on the Coast of Fuerteventura Island in the Canary Islands archipelago [151].

Figure 13. Structures of indocarbazoles and bisindole pyrroles produced by marine actinomycetes.
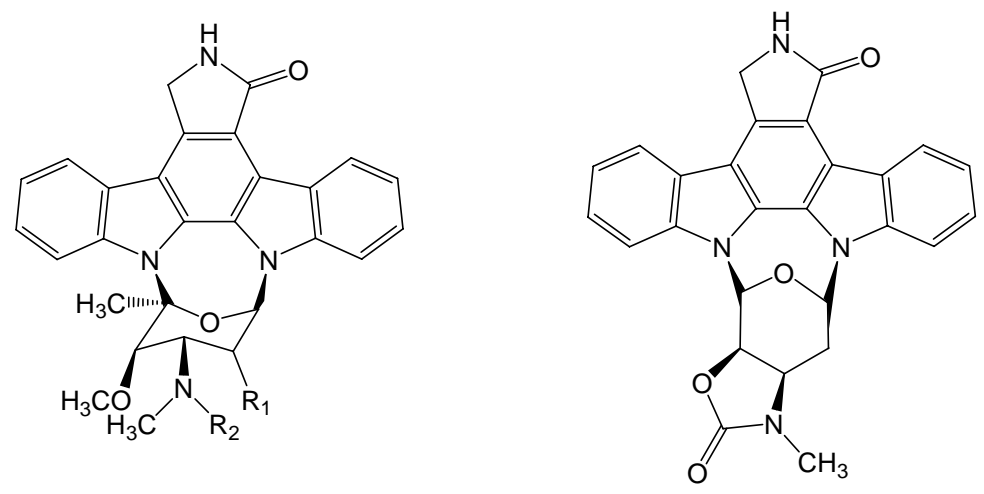

$$
\begin{array}{lll}
\text { Staurosporine } & \mathrm{R}_{1}=\mathrm{H} & \mathrm{R}_{2}=\mathrm{H} \\
\text { 4'-N-methyl-5'-hydroxystaurosporine } & \mathrm{R}_{1}=\mathrm{OH} & \mathrm{R}_{2}=\mathrm{CH}_{3} \\
\text { 5'-hydroxystaurosporine } & \mathrm{R}_{1}=\mathrm{OH} & \mathrm{R}_{2}=\mathrm{H} \\
\text { N-formyl-staurosporine } & \mathrm{R}_{1}=\mathrm{H} & \mathrm{R}_{2}=\mathrm{CHO} \\
\text { N-carboxamido-staurosporine } & \mathrm{R}_{1}=\mathrm{H} & \mathrm{R}_{2}=\mathrm{CONH}_{2}
\end{array}
$$
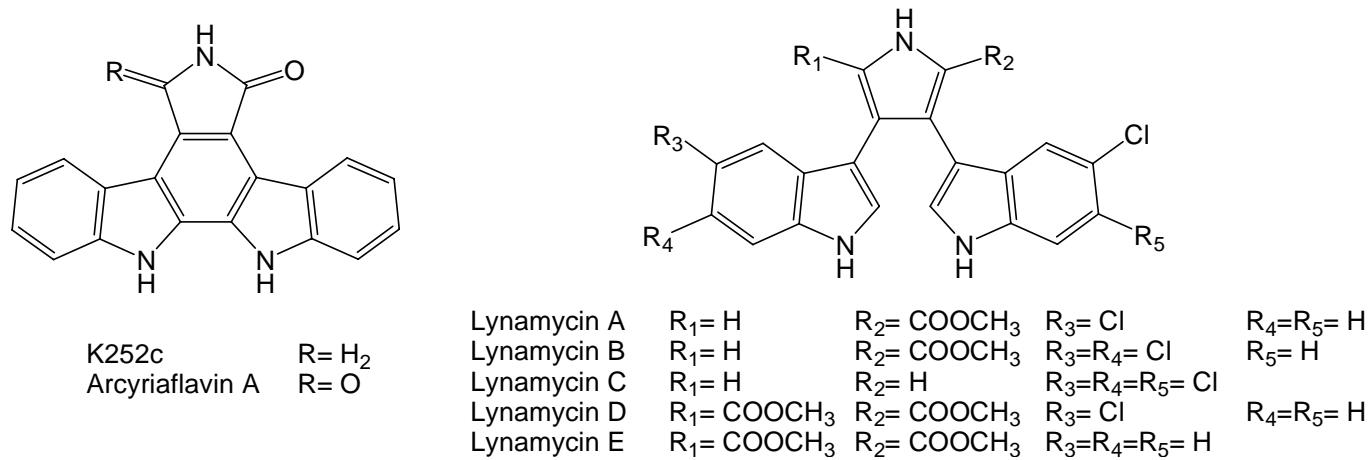

The cytotoxic activities of these indolocarbazoles were determined in vitro in cell cultures of murine macrophague $\mathrm{P}_{388 \mathrm{D}_{1}}\left(\mathrm{IC}_{50}\right.$ of $0.01,0.02$ and $\left.0.04 \mu \mathrm{g} / \mathrm{mL}\right)$, human lung adenocarcinoma $\mathrm{A} 549$ ( $\mathrm{IC}_{50}$ of $0.0005,0.002$ and $0.004 \mu \mathrm{g} / \mathrm{mL}$ ), colon adenocarcinoma HT-29 (IC $\mathrm{IC}_{50}$ of 0.02, 0.004 and 0.004 $\mu \mathrm{g} / \mathrm{mL}$ ) and melanoma SK-MEL-28 cell lines ( $\mathrm{IC}_{50}$ of $0.001,0.002$ and $0.004 \mu \mathrm{g} / \mathrm{mL}$ ). Staurosporine showed the strongest activity against $\mathrm{P} 388 \mathrm{D}_{1}$, A549 and SK-MEL-28 cell lines, while 4'- $N$-methyl-5'hydroxystaurosporine and 5'-hydroxystaurosporine were more active against HT-29 cell line [151]. $N$ formyl- and $N$-carboxamido-staurosporines have been isolated from cultures of Streptomyces sp. QD518 isolated from the Jiaozhou Bay of Quindao, China [75]. $N$-formyl- and $N$-carboxamidostaurosporines were tested in vitro for antitumoral activity in a panel of 37 human tumor cell lines derived from solid human tumors. $N$-carboxamido-staurosporine was found to be the most potent compound with a mean $\mathrm{IC}_{50}$ and $\mathrm{IC}_{70}$ values of 0.016 and $0.17 \mu \mathrm{g} / \mathrm{mL}$, respectively, while $N$-formylstaurosporine showed also high activity with mean $\mathrm{IC}_{50}$ and $\mathrm{IC}_{70}$ values of 0.063 and $0.37 \mu \mathrm{g} / \mathrm{mL}$, respectively [75]. ZHD-0501 (Figure 13) is a novel naturally occurring staurosporine analog carrying a 
heterocycle fused to the pyran ring produced by Actinomadura sp. 007, strain isolated from a sea sediment sample collected in Jiaozhou Bay, China [152]. ZHD-0501 was shown to inhibit the proliferation of human lung adenocarcinoma A549, hepatocarcinoma BEL-7402, and pro-myelocytic leukemia HL60 cancer cell lines and mouse leukemia P388 cells with the inhibition rates of 82.6\%, $57.3 \%, 76.1 \%$, and $62.2 \%$ at $1 \mu \mathrm{M}$, respectively. It also inhibited the proliferation of mouse mammary cancer tsFT210 cells, by inhibiting the cell cycle at the $\mathrm{G}_{2} / \mathrm{M}$ phase, with the inhibition rates of $28.3 \%$ at $21 \mu \mathrm{M}$ and $20.5 \%$ at $2.1 \mu \mathrm{M}[152]$.

Two known indolocarbazole alkaloids with anticancer properties, K252c (staurosporine aglycon) and arcyriaflavin $A$ (Figure 13), are produced by marine actinomycete strain $\mathrm{Z}_{2} 039-2$, isolated from the sea sediment collected on the coast of Qingdao, China. K252c was found to induce 57.3\% apoptosis on culture of human chronic myelogenous leukemia K562 cell line at $10 \mu \mathrm{M}$ and nearly $100 \%$ at $100 \mu \mathrm{M}$. In the same assay arcyriaflavin A induced $25.9 \%$ apoptosis at $10 \mu \mathrm{M}$ and up to $68.93 \%$, at $100 \mu \mathrm{M}$ [153]. K252c and arcyriaflavin A have been found, in addition, to reduced the relative resistance of cells transfected with $\mathrm{ABCG} 2$, a transporter with potential importance in cancer drug resistance, to SN-38 (7-ethyl-10-hydroxycamptothecin) in cytotoxicity assays [154]. Several analogues of K252c and arcyriaflavin A have been generated using genes involved in rebeccamycin biosynthesis [149].

Lynamicins (Figure 13) bisindole pyrroles are related to bisindolylmaleimides and indolocarbazoles due to their close structural and biosynthetic relationships [144], are produced by Marinispora sp. NPS12745 isolated from a marine sediment collected off the coast of San Diego, California. These compounds have been only tested for antimicrobial activity showing good potency against staphylococci and enterococci [155]. However, there are reports of bisindolylmaleimide derivatives with potent antitumor and antiangiogenic properties [144] and with potential to reduce resistance mediated by transporter ABCG2 [154].

\section{Others}

Marineosins (Figure 14), related to the prodigiosin class of polypyrrole bacterial pigments, are spiroaminal compounds containing two pyrrole functionalities produced by Streptomyces strain CNQ617 isolated from a marine sediment sample collected off shore of La Jolla, California. Marineosins showed significant inhibition of human colon carcinoma HCT-116 cell line with $\mathrm{IC}_{50}$ values of $0.5 \mu \mathrm{M}$ for marineosin $\mathrm{A}$ and $46 \mu \mathrm{M}$ for marineosin $\mathrm{B}$. These differences might be due to the configuration at the spiroaminal center. In addition, marineosin A showed selectivity against melanoma and leukemia cell lines in the NCI's 60 cell line panel [156]. Additionally, two known compounds of the prodigiosin family have been isolated from cultures of Saccharopolyspora sp. nov. actinomycete isolated from sponge Mycale plumose collected along the coast of Qingdao, China [157]. The compounds identified as metacycloprodigiosin and undecylprodigiosin [158,159] exhibited significant cytotoxic activities in vitro, as it has been recently described for prodigiosin family of compounds [160], against five cancer cell lines: mouse lymphoma P388, human peripheral blood promyeloblast HL60, lung carcinoma A549 and SPCA4, and hepatic carcinoma BEL-7402 with $\mathrm{IC}_{50}$ values between 0.007 and $7.52 \mu \mathrm{M}$ for metacycloprodigiosin and 0.013 to $0.11 \mu \mathrm{M}$ for undecylprodigiosin [157]. 
Streptopyrrolidine (Figure 14) is a benzyl tetrahydropyrrole derivative produced by Streptomyces sp. KORDI-3973 isolated from a deep-sea sediment sample collected at Ayu Trough, in the southern Philippine Sea. Streptopyrrolididine showed anti-angiogenesis activity on human umbilical vein endothelial cells (HUVECs) based capillary tube formation assay. The inhibition of tube formation was exerted without showing cytotoxicity against HUVECs at the concentration of $100 \mu \mathrm{g} / \mathrm{mL}$ [161].

Figure 14. Structures of polypyrrole, tetrahydropyrrole, pyrroloiminoquinone and pyrrolizidine compounds.

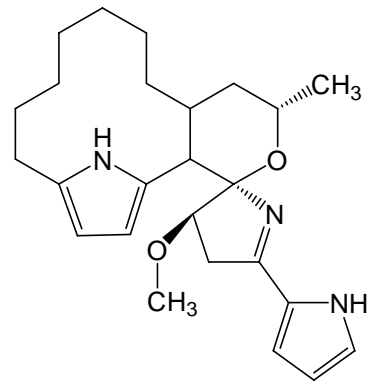

Marineosin A

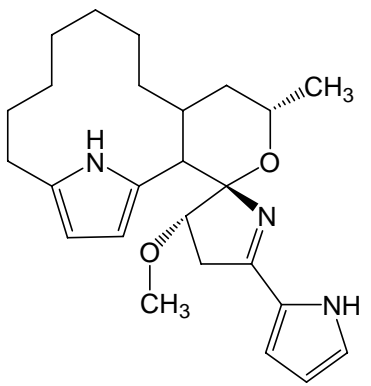

Marineosin B

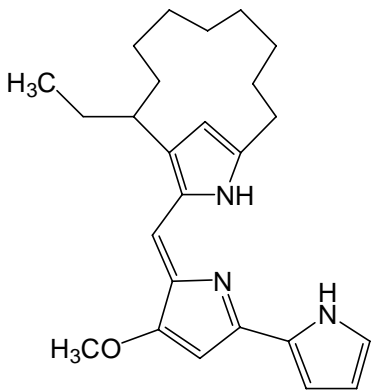

Metacycloprodigiosin

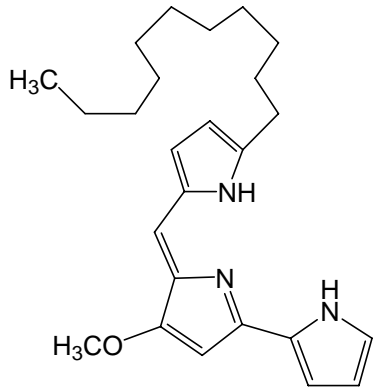

Undecylprodigiosin

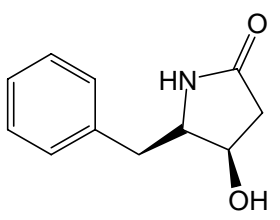

Streptopyrrolidine

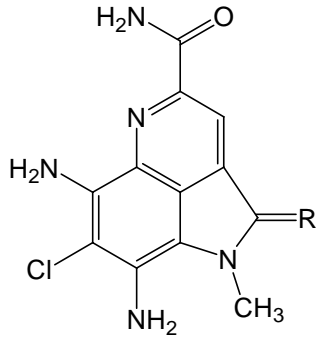

Ammosamide $\mathrm{A} \quad \mathrm{R}=\mathrm{S}$ Amomsamide $\mathrm{B} \quad \mathrm{R}=\mathrm{O}$

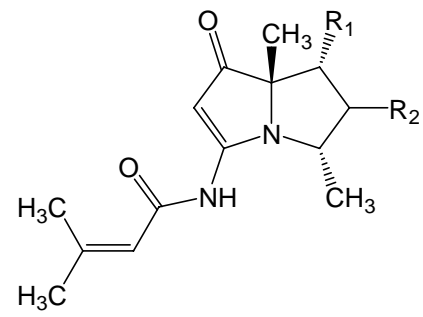

Bohemamine Bohemamine B Bohemamine $\mathrm{C}$

5-chlorobohemamine Deoxybohemamine
$\begin{array}{ll}\mathrm{R}_{1}-\mathrm{R}_{2}=\mathrm{O} & \\ \mathrm{R}_{1}=\mathrm{H} & \mathrm{R}_{2}=\mathrm{OH} \\ \mathrm{R}_{1}=\mathrm{OH} & \mathrm{R}_{2}=\mathrm{H}\end{array}$

$\begin{array}{ll}\mathrm{R}_{1}=\mathrm{OH} & \mathrm{R}_{2}=\mathrm{Cl} \\ \mathrm{R}_{1}=\mathrm{H} & \mathrm{R}_{2}=\mathrm{H}\end{array}$

Ammosamides (Figure 14) are pyrroloiminoquinone compounds produced by Streptomyces strain CNR-698 isolated from bottom sediments collected at a depth of 1,618 $\mathrm{m}$ in the Bahamas Islands. Ammosamide $\mathrm{A}$ and $\mathrm{B}$ exhibited significant in vitro cytotoxicity against human colon adenocarcinoma HCT-116 cells with an $\mathrm{IC}_{50}$ of $320 \mathrm{nM}$ each. These compounds were shown highly selective against a diversity of cancer cell lines with values ranging from $20 \mathrm{nM}$ to $1 \mu \mathrm{M}$, indicating a specific target mechanism of action that was identified as a member of the myosin family, important cellular proteins that are involved in numerous cell processes, including cell cycle regulation, cytokinesis, and cell migration [162].

Bohemamines (Figure 14) are pyrrolizidine alkaloids produced by Streptomyces strain CNQ-583 cultured from a marine sediment sample collected at a depth of $82 \mathrm{~m}$ off the island of Guam. Bohemamine, bohemamine $\mathrm{B}$, bohemamine $\mathrm{C}$ and 5-chlorobohemamine $\mathrm{C}$ were tested for inhibition of the human colon adenocarcinoma HCT-116 cell line but were found to be inactive [163]. However, bohemamine and deoxybohemamine were shown to be inhibitors of cell adhesion based on LFA1/ICAM-1 capable of inhibiting adhesion of human pro-myelocytic leukemia HL-60 cells to Chinese hamster ovary cells transfected with human ICAM-1, at $\mathrm{IC}_{50}$ values of 24.3 and $27.2 \mu \mathrm{g} / \mathrm{mL}$, respectively [164]. The interaction between LFA-1, also frequently expressed on hematopoietic and 
solid cancer cell types, and ICAM-1, that in its circulating form promotes angiogenesis and alters cancer cell behavior, is implicated in inflammatory pathologies, autoimmune diseases and in many cancer processes such as cancer metastasis from gastrointestinal carcinoma, melanoma and lymphoma. This interaction is a promising target for the development of new therapeutic agents $[165,166]$.

Three new cytotoxic 3,6-disubstituted indoles (Figure 15), with an isoprene unit at carbon 6, were isolated from Streptomyces strain BL-49-58-005 isolated from an unidentified marine invertebrate collected in México. These compounds are probably the products of different steps along the same biosynthetic pathway starting from tryptophan or tryptamine as presumed precursors. These indole compounds were assayed against a panel of 14 different tumor cell lines. Indole 1 (6-prenyltryptophol) showed the best activity against human leukemia K-562 cell line with a $\mathrm{GI}_{50}$ value of $8.46 \mu \mathrm{M}$. The aldoxime indole 2 showed activity with $\mathrm{GI}_{50}$ values within $\mu \mathrm{M}$ range against human prostate cancer LN-caP, endothelial cancer HMEC1, leukemia K-562, pancreatic carcinoma PANC1, and colon adenocarcinoma LOVO and LOVO-DOX cell lines. Nitrile indole 3 showed no activity [167]. Streptochlorin (Figure 15) is a 3-substituted indole compound with antiangiogenic and anticancer activities produced by Streptomyces strain 04DH110 isolated from shallow water sediment taken at 1 $m$ depth of Ayajin Bay, on the East Sea of Korea. Streptochlorin exhibited significant in vitro growth inhibitory activity against human leukemia K-562 cells with an $\mathrm{IC}_{50}$ of $1.05 \mu \mathrm{g} / \mathrm{mL}$ [168]. The apoptosis effect induced by streptochlorin was investigated in human leukemic U937 and hepatocarcinoma Hep3B cells showing it was correlated with a decrease in the mitochondrial membrane potential, activation of caspase-3, and down-regulation of antiapoptotic Bcl-2 protein. Those effects were exerted through production of reactive oxygen species in Hep3B cells. In U937 cells up-regulation of pro-apoptotic Bax and FasL, and degradation of poly-(ADP-ribose)polymerase and phospholipase $\mathrm{C}-\gamma 1$ protein was also observed $[169,170]$. Streptochlorin was found to have, in addition, a potent antiangiogenic activity by inhibition of endothelial cell invasion and tube formation stimulated with vascular endothelial cell growth factor, probably by inhibition of TNF- $\alpha$-induced NF$\kappa \mathrm{B}$ activation [171].

Caboxamycin (Figure 15) is a benzoxazole compound produced by Streptomyces sp. NTK 937 isolated from an Atlantic Ocean deep-sea sediment collected in the Canary Basin. It was tested against different tumor cell lines and showed moderate growth inhibitory activity towards human gastric adenocarcimona AGS, hepatocellular carcinoma Hep G2 and breast carcinoma MCF7 cell lines with $\mathrm{GI}_{50}$ of 7.5, 7.4 and $7.3 \mu \mathrm{g} / \mathrm{mL}$, respectively [172].

Streptokordin (Figure 15) is a methylpyridine compound produced by Streptomyces Sp. KORDI3238 isolated from deep-sea sediments at Ayu Trough. It exhibited significant in vitro antitumor activity against human breast cancer MDA-MB-231, colon cancer HCT 15, prostate cancer PC-3, lung cancer NCI-H23, renal cancer ACHN, skin cancer LOX-IMVI and leukemia K-562 cell lines with IC $_{50}$ values raging from 3.2 to $8.6 \mu \mathrm{g} / \mathrm{mL}$. Streptokordin did not show inhibitory effect at the concentration of $1 \mathrm{mg} / \mathrm{mL}$ on the growth of any Gram-positive or -negative bacteria or fungus tested [70].

S. luteoverticillatum 11014 [173] isolated from underwater sediment at $20 \mathrm{~m}$ depth collected off the coast of Taipingjiao, Qingdao, China, is the producer of four known butenolides: $(4 S)-4,10$-dihydroxy10-methyl-undec-2-en-1,4-olide [174], (4S)-4,10-dihydroxy-10-methyl-dodec-2-en-1,4-olide [174,175], and two diastereomeric (4S)-4,11-dihydroxy-10-methyl-dodec-2-en-1,4-olides (Figure 15) [175]. The four butenolides showed cytotoxic activity against human leukemia K562 with $\mathrm{IC}_{50}$ values 
of $8.73,6.29$, and $1.05 \mu \mathrm{mol} / \mathrm{mL}$ and murine lymphoma P388 cell lines with $\mathrm{IC}_{50}$ values of $0.34,0.19$, and $0.18 \mu \mathrm{mol} / \mathrm{mL}$, respectively. The mixture of butenolides 3 and 4, (4S)-4,11-dihydroxy-10-methyldodec-2-en-1,4-olides, was the most active, but it was unknown if both of the diastereomers were active [173].

Figure 15. Structure of indole, benzoxazole, methylpiridine and butenolide compounds.
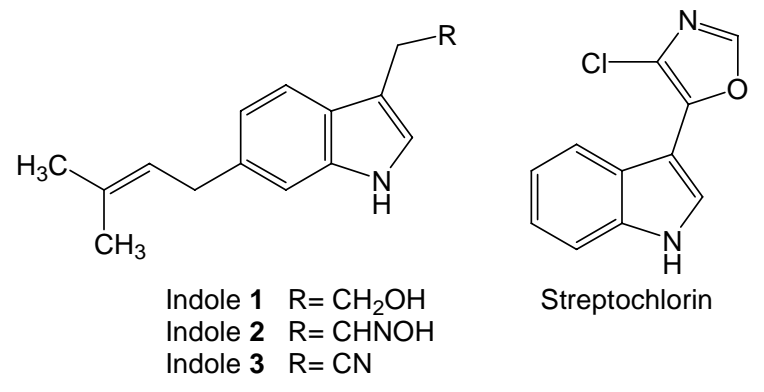

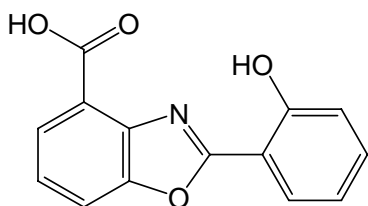

Caboxamycin<smiles>CC(=O)c1cc(C)[nH]c(=O)c1</smiles>

Streptokordin<smiles>[R]C(C)(O)CCCCC[C@H]1C=CC(=O)O1</smiles>

Butenolide 1: (4S)-4,10-dihydroxy-10-methyl-undec-2-en-1,4-olide $\mathrm{R}=\mathrm{CH}_{3}$ Butenolide 2: (4S)-4,10-dihydroxy-10-methyl-dodec-2-en-1,4-olide $\mathrm{R}=\mathrm{CH}_{2}-\mathrm{CH}_{3}$<smiles>CC(CCCCC[C@@H]1C=CC(=O)O1)[C@@H](C)O</smiles>

Butenolides 3-4: (4S)-4,11-dihydroxy-10-methyl-dodec-2-en-1,4-olides

Actinomadura sp. M048 derived from sediments of Jiaozhou Bay in China is the producer of known phenazine compounds iodinin [176] and 1,6-phenazinediol [177], the phenoxazin-3-one compounds questiomycin $\mathrm{A}$ and $\mathrm{N}$-acetylquestiomycin $\mathrm{A}$ [178], and three new phenoxazin-3-one antibiotics chandrananimycins A, B and C (Figure 16) [179]. Questiomycins and chandrananimycins were found to be active against human colon carcinoma CCL HT29, melanoma MEXF 514L, lung carcinoma LXFA 526L and LXFL 529L, breast carcinoma CNCL SF268, LCL H460 and MACL MCF-7, prostate cancer PRCL PC3M and renal cancer RXF 631L cell lines with $\mathrm{IC}_{70}$ values down to 1.4 $\mu \mathrm{g} / \mathrm{mL}$. Iodinin and 1,6-phenazinediol exhibited antitumor activity against the human lung carcinoma LXFA 629L and LXFL 529L, breast cancer MAXF 401NL, melanoma MEXF 462NL, renal cancer RXF 944L and uterus cancer UXF $1138 \mathrm{~L}$ cell lines with $\mathrm{IC}_{50}$ values of 3.6 and $3.2 \mu \mathrm{g} / \mathrm{mL}$, respectively [179].

Echinosporin and 7-deoxyechinosporin (Figure 16), tricyclic acetal-lactones, are produced by $S$. albogriseolus A2002 isolated from a sea sediment sample collected in Jiaozhou Bay, China [180] and have been previously described as produced by S. echinosporus MK-213 [181] and by Sac. erythraea Tü 4015 (formerly $S$. erythraeus) where it was shown by feeding experiments that echinosporin is synthesized by the shikimate pathway with chorismate as a biosynthetic intermediate [182]. Echinosporin was shown to inhibit the proliferation of human myelogenous leukemia K562, colon carcinoma HCT-15 and mouse mammary carcinoma tsFT210 cell lines in vitro [180], human breast adenocarcinoma MCF7, hepatocellular carcinoma Huh7 and HepG2 cell lines in vitro [182] and on rodent tumor models such as leukemia P388, P388/VCR, and fibrosarcoma Meth 1 in vivo [183]. 7- 
deoxyechinosporin showed a weaker effect than echinosporin on K562, HCT-15 and tsFT210 cell lines [180]. Both compounds were shown to arrest the cell cycle of K562, HCT-15 and tsFT210 cells mainly at the $\mathrm{G}_{2} / \mathrm{M}$ phase and to induce apoptosis in these cells [180].

Figure 16. Structures of phenazine, phenoxazin-3-one and tricyclic acetal-lactone compounds.<smiles>[O-][n+]1c2cccc(O)c2[n+]([O-])c2cccc(O)c21</smiles><smiles>[R2]Nc1cc2nc3c([R1])cccc3oc-2cc1=O</smiles>

Questiomycin A $N$-acetylquestiomycin A Chandrananimycin A Chandrananimycin B<smiles>Oc1cccc2nc3c(O)cccc3nc12</smiles>

1,6-phenazinediol<smiles>COC1CC(C)NC2=C1C1=Nc3ccccc3OC2=CC1=O</smiles>

Chandrananimycin C

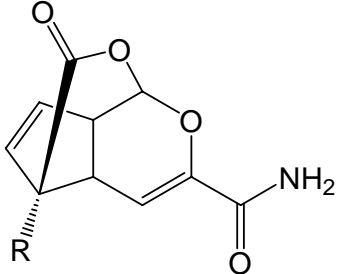

Echinosporin $\quad \mathrm{R}=\mathrm{OH}$ 7-deoxyechinosporin $\mathrm{R}=\mathrm{H}$

Apart of the antitumor compounds produced by marine actinomycetes depicted above, there are several additional compounds with antitumor activity like the topoisomerase I inhibitors cyclopropane and 14-methylhexadecanoic fatty acids produced by Streptomyces sp. strain KM86-913, isolated from a marine sponge collected under the seashore of Keomun Island, Korea [184]. In other cases the compounds identified are yet uncharacterized as is the case of light-activated cytotoxic compounds produced by different microorganisms, including actinomycetes isolated from marine sponges collected from various places in the coast of Peninsular Malaysia [185].

\section{Conclusions}

Actinomycetes and, in particular the genus Streptomyces, have been well known during the last seventy years as prolific producers of new bioactive compounds, antitumor drugs included. With the increasing development of oceanographic studies leading to the isolation of new actinomycetes from marine sources, new prolific genera in the production of useful compounds have been found, such as Salinispora. However, the Ocean, without any doubt, is keeping a myriad of new actinomycetes providing novel structural diversity to be discovered and used. In addition, the continuous effort for unravel the biosynthesis of the already known compounds and the isolation and characterization of their biosynthesis gene clusters will lead to the development of new antitumor compounds, hopefully with improved therapeutic properties, by using combinatorial biosynthesis approaches. 


\section{Acknowledgements}

This research was supported by the Spanish Ministry of Science and Innovation (BFU2006-00404 to J.A.S. and BIO2005-04115 to C.M.), Red Temática de Investigación Cooperativa de Centros de Cáncer (Ministry of Health, ISCIII-RETIC RD06/0020/0026) and the EU FP6 (ActinoGen; Integrated project $n^{\circ}$ 005224). We thank Obra Social Cajastur for financial support to Carlos Olano.

\section{References}

1. Ventura, M.; Canchaya, C.; Tauch, A.; Chandra, G.; Fitzgerald, G.F.; Chater, K.F.; van Sinderen, D. Genomics of Actinobacteria: Tracing the evolutionary history of an ancient phylum. Microbiol. Mol. Biol. Rev. 2007, 71, 495-548.

2. Goodfellow, M.; Williams, S.T. Ecology of actinomycetes. Annu. Rev. Microbiol. 1983, 37, 189216.

3. McCarthy, A.J.; Williams, S.T. Actinomycetes as agents of biodegradation in the environment-a review. Gene 1992, 115, 189-192.

4. Stach, J.E.; Bull, A.T. Estimating and comparing the diversity of marine actinobacteria. Antonie van Leeuwenhoek 2005, 87, 3-9.

5. Wilkins, K. Volatile metabolites from actinomycetes. Chemosphere 1996, 32, 1427-1434.

6. Schrempf, H. Recognition and degradation of chitin by streptomycetes. Antonie van Leeuwenhoek 2001, 79, 285-289.

7. Berdy, J. Bioactive microbial metabolites. J. Antibiot. 2005, 58, 1-26.

8. Newman, D.J.; Cragg, G.M. Natural products as sources of new drugs over the last 25 years. $J$. Nat. Prod. 2007, 70, 461-477.

9. Olano, C; Méndez, C.; Salas, J.A. Antitumor compounds from actinomycetes: from gene clusters to new derivatives by combinatorial biosynthesis. Nat. Prod. Rep. 2009, 26, 628-660.

10. Demain, A.L.; Sánchez, S. Microbial drug discovery: 80 years of progress. J. Antibiot. 2009, 62, 5-16.

11. Baltz, R.H. Renaissance in antibacterial discovery from actinomycetes. Curr. Opin. Pharmacol. 2008, 8, 557-563.

12. Ghanem, N.B.; Sabry, S.A.; El-Sherif, Z.M.; Abu El-Ela G.A. Isolation and enumeration of marine actinomycetes from seawater and sediments in Alexandria. J. Gen. Appl. Microbiol. 2000, 46, 105-111.

13. Zheng, Z.; Zeng, W.; Huang, Y.; Yang, Z.; Li, J.; Cai, H.; Su, W. Detection of antitumor and antimicrobial activities in marine organism associated actinomycetes isolated from the Taiwan Strait, China. FEMS Microbiol. Lett. 2000, 188, 87-91.

14. Fiedler, H.P.; Bruntner, C.; Bull, A.T.; Ward, A.C.; Goodfellow, M.; Potterat, O.; Puder, C.; Mihm, G. Marine actinomycetes as a source of novel secondary metabolites. Antonie van Leeuwenhoek 2005, 87, 37-42.

15. Ward, A.C.; Bora, N. Diversity and biogeography of marine actinobacteria. Curr. Opin. Microbiol. 2006, 9, 1-8. 
16. Fenical, W.; Jensen, P.R. Developing a new resource for drug discovery: marine actinomycete bacteria. Nat. Chem. Biol. 2006, 2, 666-673.

17. Panthom-Aree, W.; Stach, J.E.M.; Ward, A.C.; Horikoshi, K.; Bull, A.T.; Goodfellow, M. Diversity of actinomycetes isolated from challenger deep sediment $(10,898 \mathrm{~m})$ from the Mariana Trench. Extremophiles 2006, 10, 181-189.

18. Bull, A.T.; Stach, J.E.M. Marine actinobacteria: new opportunities for natural product search and discovery. Trends Microbiol. 2007, 15, 491-499.

19. Gontang, E.A.; Fenical, W.; Jensen, P.R. Phylogenetic diversity of Gram-positive bacteria cultured from marine sediments. Appl. Environ. Microbiol. 2007, 73, 3272-3282.

20. Bredholdt, H.; Galatenko, O.A.; Engelhardt, K.; Fjærvik, E.; Terekhova, L.P.; Zotchev, S.B. Rare actinomycete bacteria from the shallow water sediments of the Trodheim fjord, Norway: isolation, diversity and biological activity. Environ. Microbiol. 2007, 9, 2756-2764.

21. Jensen, P.R.; Lauro, F.M. An assessment of actinobacterial diversity in the marine environment. Antonie van Leeuwenhoek 2008, 94, 51-62.

22. Anzai, K.; Nakashima, T.; Kuwahara, N.; Suzuki, R.; Ohfuku, Y.; Takeshita, S.; Ando, K. Actinomycete bacteria isolated from the sediments at coastal and offshore area of Nagasaki Prefecture, Japan: diversity and biological activity. J. Biosci. Bioeng. 2008, 106, 215-217.

23. Hong, K.; Gao, A.H.; Xie, Q.Y.; Gao, H.; Zhuang, L.; Lin, H.P.; Yu, H.P.; Li, J.; Yao, X.S.; Goodfellow, M.; Ruan, J.S. Actinomycetes for marine drug discovery isolated from mangrove soils and plants in China. Mar. Drugs 2009, 7, 24-44.

24. Maldonado, L.A.; Fragoso-Yáñez, D.; Pérez-García, A.; Rosellón-Druker, J.; Quintana, E.T. Actinobacterial diversity from marine sediments collected in México. Antonie van Leeuwenhoek 2009, 95, 111-120.

25. Bernan, V.S.; Greenstein, M.; Carter, G.T. Mining marine microorganisms as a source of new antimicrobials and antifungals. Curr. Med. Chem. Anti-Infective Agents 2004, 3, 181-195.

26. Piel, J. Metabolites from symbiotic bacteria. Nat. Prod. Rep. 2004, 21, 519-538.

27. Kim, T.K.; Fuerst, J.A. Diversity of polyketide synthase genes from bacteria associated with the marine sponge Pseudoceratina clavata: culture-dependent and culture-independent approaches. Environ. Microbiol. 2006, 8, 1460-1470.

28. Blunt, J.W.; Copp, B.R.; Munro, M.H.; Northcote, P.T.; Prinsep, M.R. Marine natural products. Nat. Prod. Rep. 2006, 23, 26-78.

29. Mayer, A.M.; Rodríguez, A.D.; Berlinck, R.G.; Hamann, M.T. Marine pharmacology in 2003-4: Marine compounds with anthelmintic antibacterial, anticoagulant, antifungal, anti-inflammatory, antimalarial, antiplatelet, antiprotozoal, antituberculosis, and antiviral activities; affecting the cardiovascular, immune and nervous systems, and other miscellaneous mechanisms of action. Comp. Biochem. Physiol. 2007, 145, 553-581.

30. Williams, P.G. Panning for chemical gold: marine bacteria as a source of new therapeutics. Trends Biotechnol. 2009, 27, 45-52.

31. Blunt, J.W.; Copp, B.R.; Hu, W.P.; Munro, M.H.; Northcote, P.T.; Prinsep, M.R. Marine natural products. Nat. Prod. Rep. 2009, 26, 170-244.

32. Fenical, W.; Sethna, K.M.; Lloyd, G.K. Marine microorganisms as a developing resource for drug discovery. Pharm. News 2002, 9, 489-494. 
33. Tsueng, G.; Teisan, S.; Lam, K.S. Defined salt formulations for the growth of Salinispora tropica strain NPS21184 and the production of salinosporamide A (NPI-0052) and related analogs. Appl. Microbiol. Biotechnol. 2008, 78, 827-832.

34. Janssen, P.H.; Yates, P.S.; Grinton, B.E.; Taylor, P.M.; Sait, M. Improved culturability of soil bacteria and isolation in pure culture of novel members of the divisions Acidobacteria, Actinobacteria, Proteobacteria, and Verrucomicrobia. Appl. Environ. Microbiol. 2002, 68, 23912396.

35. Donadio, S.; Monciardini, P.; Alduina, R.; Mazza, P.; Chiocchini, C.; Cavaletti, L.; Sosio, M.; Puglia, A.M. Microbial technologies for the discovery of novel bioactive metabolites. $J$. Biotechnol. 2002, 99, 187-198.

36. Bull, A.T.; Stach, J.E. Marine actinobacteria: new opportunities for natural product search and discovery. Trends Microbiol. 2007, 15, 491-499.

37. Bull, A.T.; Stach, J.E.; Ward, A.C.; Goodfellow, M. Marine actinobacteria: perspectives, challenges, future directions. Antonie van Leeuwenhoek 2005, 87, 65-79.

38. Lam, K.S.; Tsueng, G.; McArthur, K.A.; Mitchell, S.S.; Potts, B.C.; Xu, J. Effects of halogens on the production of salinosporamides by the obligate marine actinomycete Salinispora tropica. J. Antibiot. 2007, 60, 13-19.

39. Selvin, J.; Shanmughapriya, S.; Gandhimathi, R.; Seghal Kiran, G.; Rajeetha Ravji, T.; Natarajaseenivasan, K.; Hema, T.A. Optimization and production of novel antimicrobial agents from sponge associated marine actinomycetes Nocardiopsis dassonvillei MAD08. Appl. Microbiol. Biotechnol. 2009, 83, 435-445.

40. Moore, B.S.; Kalaitzis, J.A.; Xiang, L. Exploiting marine actinomycete biosynthetic pathways for drug discovery. Antonie van Leeuwenhoek 2005, 87, 49-57.

41. Hou, Y.H.; Wang, Q.F.; Ding, L.; Li, F.C.; Qin, S. attB site disruption in marine Actinomyces sp. M048 via DNA transformation of a site-specific integration vector. Biotechnol. Appl. Biochem. 2008, 50, 11-16.

42. Shen, B. Polyketide biosynthesis beyond the type I, II and III polyketide synthase paradigms. Curr. Opin. Chem. Biol. 2003, 7, 285-295.

43. Gokhale, R.S.; Sankaranarayanan, R.; Mohanty, D. Versatility of polyketide synthases in generating metabolic diversity. Curr. Opin. Struct. Biol. 2007, 17, 736-743.

44. Williams, P.G.; Miller, E.D.; Asolkar, R.N.; Jensen, P.R; Fenical, W. Arenicolides A-C, 26membered ring macrolides from the marine actinomycete Salinispora arenicola. J. Org. Chem. 2007, 72, 5025-5034.

45. Williams, P.G.; Asolkar, R.N.; Kondratyuk, T.; Pezzuto, J.M.; Jensen, P.R.; Fenical, W. Saliniketals A and B, bicyclic polyketides from the marine actinomycete Salinispora arenicola. J. Nat. Prod. 2007, 70, 83-88.

46. Gerner, E.W.; Meyskens, F.L., Jr. Polyamines and cancer: old molecules, new understanding. Nat. Rev. Cancer 2004, 4, 781-792.

47. Cañedo, L.M.; Fernández-Puentes, J.L.; Baz, J.P. IB-96212, a novel cytotoxic macrolide produced by a marine Micromonospora. II. Physico-chemical properties and structure determination. J. Antibiot. 2000, 53, 479-483. 
48. Fernández-Chimeno, R.I.; Cañedo, L.; Espliego, F.; Grávalos, D.; De La Calle, F.; FernándezPuentes, J.L.; Romero, F. IB-96212, a novel cytotoxic macrolide produced by a marine Micromonospora. I. Taxonomy, fermentation, isolation and biological activities. J. Antibiot. 2000, 53, 474-478.

49. Wu, S.J.; Fotso, S.; Li, F.; Qin, S.; Laatsch, H. Amorphane sesquiterpenes from a marine Streptomyces sp. J. Nat. Prod. 2007, 70, 304-306.

50. Asolkar, R.N.; Maskey, R.P.; Helmke, E.; Laatsch, H. Chalcomycin B, a new macrolide antibiotic from the marine isolate Streptomyces sp. B7064. J. Antibiot. 2002, 55, 893-898.

51. Gupta, R.S.; Murray, W.; Gupta, R. Cross resistance pattern towards anticancer drugs of a human carcinoma multidrug-resistant cell line. Br. J. Cancer 1988, 58, 441-447.

52. Ward, S.L.; Hu, Z.; Schirmer, A.; Reid, R.; Revill, W.P.; Reeves, C.D.; Petrakovsky, O.V.; Dong, S.D.; Katz, L. Chalcomycin biosynthesis gene cluster from Streptomyces bikiniensis: novel features of an unusual ketolide produced through expression of the chm polyketide synthase in Streptomyces fradiae. Antimicrob. Agents Chemother. 2004, 48, 4703-4712.

53. Mitchell, S.S.; Nicholson, B.; Teisan, S.; Lam, K.S.; Potts, B.C. Aureoverticillactam, a novel 22atom macrocyclic lactam from the marine actinomycete Streptomyces aureoverticillatus. J. Nat. Prod. 2004, 67, 1400-1402.

54. Kwon, H.C.; Kauffman, C.A.; Jensen, P.R.; Fenical, W. Marinomycins A-D, antitumorantibiotics of a new structure class from a marine actinomycete of the recently discovered genus "Marinispora". J. Am. Chem. Soc. 2006, 128, 1622-1632.

55. Hara, M.; Akasaka, K.; Akinaga, S.; Okabe, M.; Nakano, H.; Gomez, R.; Wood, D.; Uh, M.; Tamanoi, F. Identification of Ras farnesyltransferase inhibitors by microbial screening. Proc. Natl. Acad. Sci. USA 1993, 90, 2281-2285.

56. Sattler, I.; Thiericke, R.; Zeeck, A. The manumycin-group metabolites. Nat. Prod. Rep. 1998, 15, 221-240.

57. Li, F.; Maskey, R.P.; Qin, S.; Sattler, I.; Fiebig, H.H.; Maier, A.; Zeeck, A.; Laatsch, H. Chinikomycins A and B: isolation, structure elucidation, and biological activity of novel antibiotics from a marine Streptomyces sp. isolate M045. J. Nat. Prod. 2005, 68, 349-353.

58. Asolkar, R.N.; Jensen, P.R.; Kauffman, C.A.; Fenical, W. Daryamides A-C, weakly cytotoxic polyketides from a marine-derived actinomycete of the genus Streptomyces strain CNQ-085. J. Nat. Prod. 2006, 69, 1756-1759.

59. Davidson, B.; Ireland, C.M. Lissoclinolide, the first non-nitrogenous metabolite from a Lissoclinum tunicate. J. Nat. Prod. 1990, 53, 1036-1038.

60. Gallo, G.G.; Coronelli, C.; Vigevani, A.; Lancini, G.C. The structure of tetrenolin: a new antibiotic substance. Tetrahedron 1969, 25, 5677-5680.

61. Pagani, H.; Lancini, G.; Tamoni, G.; Coronelli, C. Tetrenolin and SS/1018 A, antibacterial agents isolated from a strain of actinomycetales. J. Antibiot. 1973, 26, 1-6.

62. Richardson, A.D.; Ireland, C.M. A profile of the in vitro antitumor activity of lissoclinolide. Toxicol. Appl. Pharmacol. 2004, 195, 55-61.

63. Oh, D.C.; Gontang, E.A.; Kauffman, C.A.; Jensen, P.R.; Fenical, W. Salinipyrones and pacificanones, mixed-precursor polyketides from the marine actinomycete Salinispora pacifica. J. Nat. Prod. 2008, 71, 570-575. 
64. Buchanan, G.O.; Williams, P.G.; Feling, R.H.; Kauffman, C.A.; Jensen, P.R.; Fenical W. Sporolides A and B: structurally unprecedented halogenated macrolides from the marine actinomycete Salinispora tropica. Org. Lett. 2005, 7, 2731-2734.

65. Cho, J.Y.; Kwon, H.C.; Williams, P.G.; Kauffman, C.A.; Jensen, P.R.; Fenical, W. Actinofuranones $\mathrm{A}$ and $\mathrm{B}$, polyketides from a marine-derived bacterium related to the genus Streptomyces (actinomycetales). J. Nat. Prod. 2006, 69, 425-428.

66. Oh, D.C.; Williams, P.G.; Kauffman, C.A.; Jensen, P.R.; Fenical, W. Cyanosporasides A and B, chloro- and cyano-cyclopenta[a]indene glycosides from the marine actinomycete "Salinispora pacifica". Org. Lett. 2006, 8, 1021-1024.

67. Hayakawa, Y.; Shirasaki, S.; Kawasaki, T.; Matsuo, Y.; Adachi, K.; Shizuri, Y. Structures of new cytotoxic antibiotics, piericidins $\mathrm{C}_{7}$ and $\mathrm{C}_{8}$. J. Antibiot. 2007, 60, 201-203.

68. Morgenbesser, S.D.; Williams, B.O.; Jacks, T.; DePinho, R.A. p53-dependent apoptosis produced by Rb-deficiency in the developing mouse lens. Nature 1994, 371, 72-74.

69. Hayakawa, Y.; Shirasaki, S.; Shiba, S.; Kawasaki, T.; Matsuo, Y.; Adachi, K.; Shizuri, Y. Piericidins $\mathrm{C}_{7}$ and $\mathrm{C}_{8}$, new cytotoxic antibiotics produced by a marine Streptomyces sp. $J$. Antibiot. 2007, 60, 196-200.

70. Jeong, S.Y.; Shin, H.J.; Kim, T.S.; Lee, H.S.; Park, S.K.; Kim, H.M. Streptokordin, a new cytotoxic compound of the methylpyridine class from a marine-derived Streptomyces sp. KORDI-3238. J. Antibiot. 2006, 59, 234-240.

71. Smith, W.C.; Xiang, L.; Shen, B. Genetic localization and molecular characterization of the nonS gene required for macrotetrolide biosynthesis in Streptomyces griseus DSM40695. Antimicrob. Agents. Chemother. 2000, 44, 1809-1817.

72. Borrel, M.N.; Pereira, E.; Fiallo, M.; Garnier-Suillerot, A. Mobile ionophores are a novel class of P-glycoprotein inhibitors. The effects of ionophores on 4'-O-tetrahydropyranyl-adriamycin incorporation in K562 drug-resistant cells. Eur. J. Biochem. 1994, 223, 125-133.

73. Itoh, T.; Kinoshita, M.; Wei, H.; Kobayashi, M. Stereostructure of komodoquinone A, a neuritogenic anthracycline, from marine Streptomyces sp. KS3. Chem. Pharm. Bull. 2003, 51, 1402-1404.

74. Itoh, T.; Kinoshita, M.; Aoki, S.; Kobayashi, M. Komodoquinone A, a novel neuritogenic anthracycline, from marine Streptomyces sp. KS3. J. Nat. Prod. 2003, 66, 1373-1377.

75. Wu, S.J.; Fotso, S.; Li, F.; Qin, S.; Kelter, G.; Fiebig, H.H.; Laatsch, H. 39-N-carboxamidostaurosporine and selina-4(14),7(11)-diene-8,9-diol, new metabolites from a marine Streptomyces sp. J. Antibiot. 2006, 59, 331-337.

76. Butler, M.S. Natural products to drugs: natural product-derived compounds in clinical trials. Nat. Prod. Rep. 2008, 25, 475-516.

77. Xu, Z.; Jakobi, K.; Welzel, K.; Hertweck, C. Biosynthesis of the antitumor agent chartreusin involves the oxidative rearrangement of an anthracyclic polyketide. Chem. Biol. 2005, 12, 579588.

78. Lorico, A.; Long, B.H. Biochemical characterisation of elsamicin and other coumarin-related antitumour agents as potent inhibitors of human topoisomerase II. Eur. J. Cancer 1993, 29A, 1985-1991. 
79. McGovren, J.P.; Neil, G.L.; Crampton, S.L.; Robinson, M.I.; Douros, J.D. Antitumor activity and preliminary drug disposition studies on chartreusin (NSC 5159). Cancer Res. 1977, 37, 1666-1672.

80. Maskey, R.P.; Helmke, E.; Laatsch, H. Himalomycin A and B: isolation and structure elucidation of new fridamycin type antibiotics from a marine Streptomyces isolate. J. Antibiot. 2003, 56, 942-949.

81. Masuma, R.; Tanaka, K. New antitumor antibiotics, OS-4742 A1, A2, B1 and B2 produced by a strain of Streptomyces. J. Antibiot. 1977, 30, 908-916.

82. Maskey, R.P.; Helmke, E.; Fiebig, H.H.; Laatsch, H. Parimycin: isolation and structure elucidation of a novel cytotoxic 2,3-dihydroquinizarin analogue of gamma-indomycinone from a marine streptomycete isolate. J. Antibiot. 2002, 55, 1031-1035.

83. Maskey, R.P.; Helmke, E.; Kayser, O.; Fiebig, H.H.; Maier, A.; Busche, A.; Laatsch, H. Anticancer and antibacterial trioxacarcins with high anti-malaria activity from a marine streptomycete and their absolute stereochemistry. J. Antibiot. 2004, 57, 771-779.

84. Maskey, R.P.; Sevvana, M.; Usón, I.; Helmke, E.; Laatsch, H. Gutingimycin: a highly complex metabolite from a marine streptomycete. Angew. Chem. Int. Ed. Engl. 2004, 43, 1281-1283.

85. Fitzner, A.; Frauendorf, H.; Laatsch, H.; Diederichsen, U. Formation of gutingimycin: analytical investigation of trioxacarcin A-mediated alkylation of dsDNA. Anal. Bioanal. Chem. 2008, 390, 1139-1147.

86. Huang, Y.F.; Tian, L.; Fu, H.W.; Hua, H.M.; Pei, Y.H. One new anthraquinone from marine Streptomyces sp. FX-58. Nat. Prod. Res. 2006, 20, 1207-1210.

87. Gorajana, A.; Kurada, B.V.; Peela, S.; Jangam, P.; Vinjamuri, S.; Poluri, E.; Zeeck, A. 1Hydroxy-1-norresistomycin, a new cytotoxic compound from a marine actinomycete, Streptomyces chibaensis $\mathrm{AUBN}_{1}$ /7. J. Antibiot. 2005, 58, 526-529.

88. Kock, I.; Maskey, R.P.; Biabani, M.A.; Helmke, E.; Laatsch, H. 1-Hydroxy-1-norresistomycin and resistoflavin methyl ether: new antibiotics from marine-derived streptomycetes. J. Antibiot. 2005, 58, 530-534.

89. Martin, P.; Rodier, S.; Mondon, M.; Renoux, B.; Pfeiffer, B.; Renard, P.; Pierre, A.; Gesson, J.P. Synthesis and cytotoxic activity of tetracenomycin D and of saintopin analogues. Bioorg. Med. Chem. 2001, 10, 253-260.

90. Hutchinson, C.R. Biosynthetic studies of daunorubicin and tetracenomycin C. Chem. Rev. 1997, 97, 2525-2536.

91. Shiono, Y.; Shiono, N.; Seo, S.; Oka, S.; Yamazaki, Y. Effects of polyphenolic anthrone derivatives, resistomycin and hypercin, on apoptosis in human megakaryoblastic leukemia CMK7 cell line. Z. Naturforsch 2002, 57, 923-929.

92. Jakobi, K.; Hertweck, C. A gene cluster encoding resistomycin biosynthesis in Streptomyces resistomycificus; exploring polyketide cyclization beyond linear and angucyclic patterns. J. Am. Chem. Soc. 2004, 126, 2298-2289.

93. Gorajana, A.; Venkatesan, M.; Vinjamuri, S.; Kurada, B.V.; Peela, S.; Jangam, P.; Poluri, E.; Zeeck, A. Resistoflavine, cytotoxic compound from a marine actinomycete, Streptomyces chibaensis $\mathrm{AUBN}_{1} / 7$. Microbiol. Res. 2007, 162, 322-327. 
94. Martin, G.D.; Tan, L.T.; Jensen, P.R.; Dimayuga, R.E.; Fairchild, C.R.; Raventos-Suarez, C.; Fenical, W. Marmycins A and B, cytotoxic pentacyclic C-glycosides from a marine sedimentderived actinomycete related to the genus Streptomyces. J. Nat. Prod. 2007, 70, 1406-1409.

95. Imamura, N.; Kakinuma, K.; Ikekawa, N.; Tanaka, H.; Omura, S. Biosynthesis of vineomycins A1 and B2. J. Antibiot. 1982, 37, 602-607.

96. Kitahara, T.; Naganawa, H.; Okazaki, T.; Okami, Y.; Umezawa, H. The structure of SS-228 Y, an antibiotic from Chainia sp. J. Antibiot. 1975, 28, 280-285.

97. Okazaki, T.; Kitahara, T.; Okami, Y. Studies on marine microorganisms. IV. A new antibiotic SS-228 Y produced by Chainia isolated from shallow sea mud. J. Antibiot. 1975, 28, 176-184.

98. Malet-Cascón, L.; Romero, F.; Espliego-Vázquez, F.; Grávalos, D.; Fernández-Puentes, J.L. IB00208, a new cytotoxic polycyclic xanthone produced by a marine-derived Actinomadura. I. Isolation of the strain, taxonomy and biological activites. J. Antibiot. 2003, 56, 219-225.

99. Rodríguez, J.C.; Fernández-Puentes, J.L.; Baz, J.P.; Cañedo, L.M. IB-00208, a new cytotoxic polycyclic xanthone produced by a marine-derived Actinomadura. II. Isolation, physicochemical properties and structure determination. J. Antibiot. 2003, 56, 318-321.

100. Tresselt, D.; Eckardt, K.; Ihn, W. Antibiotics from Actinomycetes - chemical composition of antibiotic griseorhodin A. Tetrahedron 1978, 34, 2693-2699.

101. Ueno, T.; Takahashi, H.; Oda, M.; Mizunuma, M.; Yokoyama, A.; Goto, Y.; Mizushina, Y.; Sakaguchi, K.; Hayashi, H. Inhibition of human telomerase by rubromycins: Implication of spiroketal system of the compounds as an active moiety. Biochemistry 2000, 39, 5995-6002.

102. Shay, J.W.; Zou, Y.; Hiyama, E.; Wright, W.E. Telomerase and cancer. Hum. Mol. Genet. 2001, 10, 677-685.

103. Li, A.; Piel, J. A gene cluster from a marine Streptomyces encoding the biosynthesis of the aromatic spiroketal polyketide griseorhodin A. Chem. Biol. 2002, 9, 1017-1026.

104. Walsh, C.T. Polyketide and nonribosomal peptide antibiotics: modularity and versatility. Science 2004, 303, 1805-1810.

105. Sieber, S.A.; Marahiel, M.A. Molecular mechanisms underlying nonribosomal peptide synthesis: approaches to new antibiotics. Chem. Rev. 2005, 105, 715-738.

106. Fischbach, M.A; Walsh, C.T. Assembly-line enzymology for polyketide and nonribosomal Peptide antibiotics: logic, machinery, and mechanisms. Chem. Rev. 2006, 106, 3468-3496.

107. Fiedler, H.P.; Bruntner, C.; Riedlinger, J.; Bull, A.T.; Knutsen, G.; Goodfellow, M.; Jones, A.; Maldonado, L.; Pathom-aree, W.; Beil, W.; Schneider, K.; Keller, S.; Sussmuth, R.D. Proximicin $\mathrm{A}, \mathrm{B}$ and $\mathrm{C}$, novel aminofuran antibiotic and anticancer compounds isolated from marine strains of the actinomycete Verrucosispora. J. Antibiot. 2008, 61, 158-163.

108. Riedlinger, J.; Reicke, A.; Zähner, H.; Krismer, B.; Bull, A.T.; Maldonado, L.A.; Ward, A.C.; Goodfellow, M.; Bister, B.; Bischoff, D.; Süssmuth, R.D.; Fiedler, H.P. Abyssomicins, inhibitors of the para-aminobenzoic acid pathway produced by the marine Verrucosispora strain AB-18032. J. Antibiot. 2004, 57, 271-279.

109. Schneider, K.; Keller, S.; Wolter, F.E.; Röglin, L.; Beil, W.; Seitz, O.; Nicholson, G.; Bruntner, C.; Riedlinger, J.; Fiedler, H.P.; Süssmuth, R.D. Proximicins A, B, and C-antitumor furan analogues of netropsin from the marine actinomycete Verrucosispora induce upregulation of p53 and the cyclin kinase inhibitor p21. Angew. Chem. Int. Ed. Engl. 2008, 47, 3258-3261. 
110. Cho, J.Y.; Williams, P.G.; Kwon, H.C.; Jensen, P.R.; Fenical, W. Lucentamycins A-D, cytotoxic peptides from the marine-derived actinomycete Nocardiopsis lucentensis. J. Nat. Prod. 2007, 70, 1321-1328.

111. Kanoh, K.; Matsuo, Y.; Adachi, K.; Imagawa, H.; Nishizawa, M.; Shizuri, Y. Mechercharmycins $\mathrm{A}$ and B, cytotoxic substances from marine-derived Thermoactinomyces sp. YM3-251.J. Antibiot. 2005, 58, 289-292.

112. Romero, F.; Espliego, F.; Pérez Baz, J.; García de Quesada, T.; Grávalos, D.; de la Calle, F.; Fernández-Puentes, J.L. Thiocoraline, a new depsipeptide with antitumor activity produced by a marine Micromonospora. I. Taxonomy, fermentation, isolation, and biological activities. J. Antibiot. 1997, 50, 734-737.

113. Pérez Baz, J.; Cañedo, L.M.; Fernández Puentes, J.L.; Silva Elipe, M.V. Thiocoraline, a novel depsipeptide with antitumor activity produced by a marine Micromonospora. II. Physicochemical properties and structure determination. J. Antibiot. 1997, 50, 738-741.

114. Erba, E.; Bergamaschi, D.; Ronzoni, S.; Faretta, M.; Taverna, S.; Bonfanti, M.; Catapano, C.V.; Faircloth, G.; Jimeno, J.; D'Incalci, M. Mode of action of thiocoraline, a natural marine compound with anti-tumour activity. Br. J. Cancer 1999, 80, 971-980.

115. Dawson, S.; Malkinson, J.P.; Paumier, D.; Searcey, M. Bisintercalator natural products with potential therapeutic applications: isolation, structure determination, synthetic and biological studies. Nat. Prod. Rep. 2007, 24, 109-126.

116. Lombó, F.; Velasco, A.; Castro, A.; de la Calle, F.; Braña, A.F.; Sánchez-Puelles, J.M.; Méndez, C.; Salas, J.A. Deciphering the biosynthesis pathway of the antitumor thiocoraline from a marine actinomycete and its expression in two Streptomyces species. ChemBioChem 2006, 7, 366-376.

117. Asolkar, R.N.; Freel, K.C.; Jensen, P.R.; Fenical, W.; Kondratyuk, T.P.; Park, E.J.; Pezzuto, J.M. Arenamides A-C, cytotoxic NF- $\mathrm{BB}$ inhibitors from the marine actinomycete Salinispora arenicola. J. Nat. Prod. 2009, 72, 396-402.

118. Aggarwal, B.B.; Sethi, G; Nair, A.; Ichikawa, H. Nuclear factor- $\kappa$ B A holy grail in cancer prevention and therapy. Curr. Signal Transduction Ther. 2006, 1, $25-52$.

119. Melisi, D.; Chiao, P.J. NF-кB as a target for cancer therapy. Expert Opin. Ther. Targets 2007, $11,133-144$.

120. Miller, E.D.; Kauffman, C.A.; Jensen, P.R.; Fenical, W. Piperazimycins: cytotoxic hexadepsipeptides from a marine-derived bacterium of the genus Streptomyces. J. Org. Chem. 2007, 72, 323-330.

121. Feling, R.H.; Buchanan, G.O.; Mincer, T.J.; Kauffman, C.A.; Jensen, P.R.; Fenical, W. Salinosporamide A: a highly cytotoxic proteasome inhibitor from a novel microbial source, a marine bacterium of the new genus Salinospora. Angew. Chem. Int. Ed. Engl. 2003, 42, 355-357.

122. Udwary, D.W; Zeigler, L.; Asolkar, R.N.; Singan, V.; Lapidus, A.; Fenical, W.; Jensen, P.R.; Moore, B.S. Genome sequencing reveals complex secondary metabolome in the marine actinomycete Salinispora tropica. Proc. Natl. Acad. Sci. USA 2007, 104, 10376-10381.

123. Jensen, P.R.; Williams, P.G.; Oh, D.C.; Zeigler, L.; Fenical, W. Species-specific secondary metabolite production in marine actinomycetes of the genus Salinispora. Appl. Environ. Microbiol. 2007, 73, 1146-1152. 
124. Miller, C.P.; Ban, K.; Dujka, M.E.; McConkey, D.J.; Munsell, M.; Palladino, M.; Chandra, J. NPI-0052, a novel proteasome inhibitor, induces caspase- 8 and ROS-dependent apoptosis alone and in combination with HDAC inhibitors in leukemia cells. Blood 2007, 110, 267-277.

125. Beer, L.L.; Moore, B.S. Biosynthetic convergence of salinosporamides A and B in the marine actinomycete Salinispora tropica. Org. Lett. 2007, 9, 845-848.

126. Williams, P.G.; Buchanan, G.O.; Feling, R.H.; Kauffman, C.A.; Jensen, P.R.; Fenical, W. New cytotoxic salinosporamides from the marine actinomycete Salinispora tropica. J. Org. Chem. 2005, 70, 6196-6203.

127. Reed, K.A.; Manam, R.R.; Mitchell, S.S.; Xu, J.; Teisan, S.; Chao, T.H.; Deyanat-Yazdi, G.; Neuteboom, S.T.; Lam, K.S.; Potts, B.C. Salinosporamides D-J from the marine actinomycete Salinispora tropica, bromosalinosporamide, and thioester derivatives are potent inhibitors of the 20S proteasome. J. Nat. Prod. 2007, 70, 269-276.

128. Lam, K.S.; Tsueng, G.; McArthur, K.A.; Mitchell, S.S.; Potts, B.C.; Xu, J. Effects of halogens on the production of salinosporamides by the obligate marine actinomycete Salinispora tropica. J. Antibiot. 2007, 60, 13-19.

129. Eustáquio, A.S.; Moore, B.S. Mutasynthesis of fluorosalinosporamide, a potent and reversible inhibitor of the proteasome. Angew. Chem. Int. Ed. Engl. 2008, 47, 3936-3938.

130. McGlinchey, R.P.; Nett, M.; Eustáquio, A.S.; Asolkar, R.N.; Fenical, W.; Moore, B.S. Engineered biosynthesis of antiprotealide and other unnatural salinosporamide proteasome inhibitors. J. Am. Chem. Soc. 2008, 130, 7822-7823.

131. Manam, R.R.; Macherla, V.R.; Tsueng, G.; Dring, C.W.; Weiss, J.; Neuteboom, S.T.; Lam, K.S.; Potts, B.C. Antiprotealide is a natural product. J. Nat. Prod. 2009, 72, 295-297.

132. Manam, R.R.; Teisan, S.; White, D.J.; Nicholson, B.; Grodberg, J.; Neuteboom, S.T.; Lam, K.S.; Mosca, D.A.; Lloyd, G.K.; Potts, B.C. Lajollamycin, a nitro-tetraene spiro-beta-lactone-gammalactam antibiotic from the marine actinomycete Streptomyces nodosus. J. Nat. Prod. 2005, 68, 240-243.

133. Zhao, C.; Ju, J.; Christenson, S.D.; Smith, W.C.; Song, D.; Zhou, X.; Shen, B.; Deng, Z. Utilization of the methoxymalonyl-acyl carrier protein biosynthesis locus for cloning the oxazolomycin biosynthetic gene cluster from Streptomyces albus JA3453. J. Bacteriol. 2006, $188,4142-4147$.

134. Dairi, T. Studies on biosynthetic genes and enzymes of isoprenoids produced by actinomycetes. J. Antibiot. 2005, 58, 227-243.

135. Takahashi, A.; Ikeda, D.; Nakamura, H.; Naganawa, H.; Kurasawa, S.; Okami, Y.; Takeuchi, T.; Iitaka, Y. Altemicidin, a new acaricidal and antitumor substance. II. Structure determination. $J$. Antibiot. 1989, 42, 1562-1566.

136. Takahashi, A.; Kurasawa, S.; Ikeda, D.; Okami, Y.; Takeuchi, T. Altemicidin, a new acaricidal and antitumor substance. I. Taxonomy, fermentation, isolation and physico-chemical and biological properties. J. Antibiot. 1989, 42, 1556-1561.

137. Pathirana, C.; Jensen, P.R.; Fenical, W. Marinone and debromomarinone: Antibiotic sesquiterpenoid naphthoquinones of a new structure class from a marine bacterium. Tetrahedron Lett. 1992, 33, 7663-7666. 
138. Hardt, I.H.; Jensen, P.R.; Fenical, W. Neomarinone, and new cytotoxic marinone derivatives, produced by a marine filamentous bacterium (actinomycetales). Tetrahedron Lett. 2000, 41, 2073-2076.

139. Kalaitzis, J.A.; Hamano, Y.; Nilsen, G.; Moore, B.S. Biosynthesis and structural revision of neomarinone. Org. Lett. 2003, 5, 4449-4452.

140. Ding, L.; Pfoh, R.; Rühl, S.; Qin, S.; Laatsch, H. T-muurolol sesquiterpenes from the marine Streptomyces sp. M491 and revision of the configuration of previously reported amorphanes. $J$. Nat. Prod. 2009, 72, 99-101.

141. Soria-Mercado, I.E.; Prieto-Davo, A.; Jensen, P.R.; Fenical, W. Antibiotic terpenoid chlorodihydroquinones from a new marine actinomycete. J. Nat. Prod. 2005, 68, 904-910.

142. Fukuda, D.S.; Mynderse, J.S.; Baker, P.J.; Berry, D.M.; Boeck, L.D.; Yao, R.C.; Mertz, F.P.; Nakatsukasa, W.M.; Mabe, J.; Ott, J.; Counter, F.T.; Ensminger, P.W.; Allen, N.E.; Alborn, W. E.; Hobbs, J.N. A80915, a new antibiotic complex produced by Streptomyces aculeolatus. Discovery, taxonomy, fermentation, isolation, characterization, and antibacterial evaluation. $J$. Antibiot. 1990, 43, 623-633.

143. Saha, M.; Jaisankar, P.; Das, S.; Sarkar, K.K.; Roy, S.; Besra, S.E.; Vedasiromani, J.R.; Ghosh, D.; Sana, B.; Mukherjee, J. Production and purification of a bioactive substance inhibiting multiple drug resistant bacteria and human leukemia cells from a salt-tolerant marine Actinobacterium sp. isolated from the Bay of Bengal. Biotechnol. Lett. 2006, 28, 1083-1088.

144. Sánchez, C.; Méndez, C.; Salas, J.A. Indolocarbazole natural products: occurrence, biosynthesis, and biological activity. Nat. Prod. Rep. 2006, 23, 1007-1045.

145. Omura, S.; Iwai, Y.; Hirano, A.; Nakagawa, A.; Awaya, J.; Tsuchya, H.; Takahashi, Y.; Masuma, R. A new alkaloid AM-2282 of Streptomyces origin taxonomy, fermentation, isolation and preliminary characterization. J. Antibiot. 1977, 30, 275-282.

146. Onaka, H.; Taniguchi, S.; Igarashi, Y.; Furumai, T. Cloning of the staurosporine biosynthetic gene cluster from Streptomyces sp. TP-A0274 and its heterologous expression in Streptomyces lividans. J. Antibiot. 2002, 55, 1063-1071.

147. Salas, A.P.; Zhu, L.; Sánchez, C.; Braña, A.F.; Rohr, J.; Méndez, C.; Salas, J.A. Deciphering the late steps in the biosynthesis of the anti-tumour indolocarbazole staurosporine: sugar donor substrate flexibility of the StaG glycosyltransferase. Mol. Microbiol. 2005, 58, 17-27.

148. Sánchez, C.; Méndez, C.; Salas, J.A. Engineering biosynthetic pathways to generate antitumor indolocarbazole derivatives. J. Ind. Microbiol. Biotechnol. 2006, 33, 560-568.

149. Sánchez, C.; Zhu, L.; Braña, A.F.; Salas, A.P.; Rohr, J.; Méndez, C.; Salas, J.A. Combinatorial biosynthesis of antitumor indolocarbazole compounds. Proc. Natl. Acad. Sci. USA 2005, 102, 461-466.

150. Salas, J.A.; Méndez, C. Indolocarbazole antitumour compounds by combinatorial biosynthesis. Curr. Opin. Chem. Biol. 2009, 13, 152-160.

151. Hernández, L.M.; Blanco, J.A.; Baz, J.P.; Puentes, J.L.; Millán, F.R.; Vázquez, F.E.; FernándezChimeno, R.I.; Grávalos, D.G. 4'-N-methyl-5'-hydroxystaurosporine and 5'hydroxystaurosporine, new indolocarbazole alkaloids from a marine Micromonospora sp. strain. J. Antibiot. 2000, 53, 895-902. 
152. Han, X.; Cui, C.; Gu, Q.; Zhu, W.; Liu, H.; Gu, J.; Osada, H. ZHD-0501, a novel naturally occurring staurosporine analog from Actinomadura sp. 007. Tetrahedron Lett. 2005, 46, 61376140.

153. Liu, R.; Zhu, T.; Li, D.; Gu, J.; Xia, W.; Fang, Y.; Liu, H.; Zhu, W.; Gu, Q. Two indolocarbazole alkaloids with apoptosis activity from a marine-derived actinomycete Z2039-2. Arch. Pharm. Res. 2007, 30, 270-274.

154. Robey, R.W.; Shukla, S.; Steadman, K.; Obrzut, T.; Finley, E.M.; Ambudkar, S.V.; Bates, S.E. Inhibition of ABCG2-mediated transport by protein kinase inhibitors with a bisindolylmaleimide or indolocarbazole structure. Mol. Cancer. Ther. 2007, 6, 1877-1885.

155. McArthur, K.A.; Mitchell, S.S.; Tsueng, G.; Rheingold, A.; White, D.J.; Grodberg, J.; Lam, K. S.; Potts, B.C. Lynamicins A-E, chlorinated bisindole pyrrole antibiotics from a novel marine actinomycete. J. Nat. Prod. 2008, 71, 1732-1737.

156. Boonlarppradab, C.; Kauffman, C.A.; Jensen, P.R.; Fenical, W. Marineosins A and B, cytotoxic spiroaminals from a marine-derived actinomycete. Org. Lett. 2008, 10, 5505-5508.

157. Liu, R.; Cui, C.B.; Duan, L.; Gu, Q.Q.; Zhu, W.M. Potent in vitro anticancer activity of metacycloprodigiosin and undecylprodigiosin from a sponge-derived actinomycete Saccharopolyspora sp. nov. Arch. Pharm. Res. 2005, 28, 1341-1344.

158. Wasserman, H.H.; Rodgers, G.C.; Keith, D.D. Metacycloprodigiosin, a tripyrrole pigment from Streptomyces longisporusruber. J. Am. Chem. Soc. 1969, 91, 1263-1264.

159. Wasserman, H.H.; Keith, D.D.; and Rodgers, G.C. The structure of metacycloprodigiosin. Tetrahedron, 1976, 32, 1855-1861.

160. Pérez-Tomás, R.; Montaner, B.; Llagostera, E.; Soto-Cerrato, V. The prodigiosins, proapoptotic drugs with anticancer properties. Biochem. Pharmacol. 2003, 66, 1447-1452.

161. Shin, H.J.; Kim, T.S.; Lee, H.S.; Park, J.Y.; Choi, I.K.; Kwon, H.J. Streptopyrrolidine, an angiogenesis inhibitor from a marine-derived Streptomyces sp. KORDI-3973. Phytochemistry 2008, 69, 2363-2366.

162. Hughes, C.C.; MacMillan, J.B.; Gaudêncio, S.P.; Jensen, P.R.; Fenical, W. The ammosamides: structures of cell cycle modulators from a marine-derived Streptomyces species. Angew. Chem. Int. Ed. Engl. 2009, 48, 725-727.

163. Bugni, T.S.; Woolery, M.; Kauffman, C.A.; Jensen, P.R.; Fenical, W. Bohemamines from a marine-derived Streptomyces sp. J. Nat. Prod. 2006, 69, 1626-1628.

164. Zhang, Q.; Schrader, K.K.; ElSohly, H.N.; Takamatsu, S. New cell-cell adhesion inhibitors from Streptomyces sp. UMA-044. J. Antibiot. 2003, 56, 673-681.

165. Zimmerman, T.; Blanco, F.J. Inhibitors targeting the LFA-1/ICAM-1 cell-adhesion interaction: design and mechanism of action. Curr. Pharm. Des. 2008, 14, 2128-2139.

166. Cossío, F.P.; Mendoza, M.L.; Zubia, A., Valcárcel, M.; Vara, Y.I.; Solaun, M.S.; López, J.J.; San Sebastian, E. Novel inhibitors of the LFA-1/ICAM-1 interaction, and uses thereof. WIPO Patent WO/2007/054128 2007.

167. Sánchez López, J.M.; Martínez Insua, M.; Pérez Baz, J.; Fernández Puentes, J.L.; Cañedo Hernández, L.M. New cytotoxic indolic metabolites from a marine Streptomyces. J. Nat. Prod. 2003, 66, 863-864. 
168. Shin, H.J.; Jeong, H.S.; Lee, H.S.; Park, S.K.; Kim, H.M.; Kwon, H.J. Isolation and structure determination of streptochlorin, an antiproliferative agent from a marine-derived Streptomyces sp. 04DH110. J. Microbiol. Biotechnol. 2007, 17, 1403-1406.

169. Park, C.; Shin, H.J.; Kim, G.Y.; Kwon, T.K.; Nam, T.J.; Kim, S.K.; Cheong, J.; Choi, I.W.; Choi, Y.H. Induction of apoptosis by streptochlorin isolated from Streptomyces sp. in human leukemic U937 cells. Toxicol. In Vitro 2008, 22, 1573-1581.

170. Shin, D.Y.; Shin, H.J.; Kim, G.Y.; Cheong, J.; Choi, I.W.; Kim, S.K.; Moon, S.K.; Kang, H.S.; Choi, Y.H. Streptochlorin isolated from Streptomyces sp. Induces apoptosis in human hepatocarcinoma cells through a reactive oxygen species-mediated mitochondrial pathway. $J$. Microbiol. Biotechnol. 2008, 18, 1862-1868.

171. Choi, I.K.; Shin, H.J.; Lee, H.S.; Kwon, H.J. Streptochlorin, a marine natural product, inhibits $\mathrm{NF}-\kappa \mathrm{B}$ activation and suppresses angiogenesis in vitro. J. Microbiol. Biotechnol. 2007, 17, 13381343.

172. Hohmann, C.; Schneider, K.; Bruntner, C.; Irran, E.; Nicholson, G.; Bull, A.T.; Jones, A.L.; Brown, R.; Stach, J.E.; Goodfellow, M.; Beil, W.; Krämer, M.; Imhoff, J.F.; Süssmuth, R.D.; Fiedler, H.P. Caboxamycin, a new antibiotic of the benzoxazole family produced by the deep-sea strain Streptomyces sp. NTK 937. J. Antibiot. 2009, 62, 99-104.

173. Li, D.H.; Zhu, T.J.; Liu, H.B.; Fang, Y.C.; Gu, Q.Q.; Zhu, W.M. Four butenolides are novel cytotoxic compounds isolated from the marine-derived bacterium, Streptoverticillium luteoverticillatum 11014. Arch. Pharm. Res. 2006, 29, 624-626.

174. Cho, K.W.; Lee, H.S.; Rho, J.R.; Kim, T.S.; Mo, S.J.; Shin, J. New lactone-containing metabolites from a marine derived bacterium of the genus Streptomyces. J. Nat. Prod. 2001, 64, 664-667.

175. Mukku, V.J.; Speitling, M.; Laatsch, H.; Helmke, E. New butenolides from two marine streptomycetes. J. Nat. Prod. 2000, 63, 1570-1572.

176. Tsujibo, H.; Sato, T.; Inui, M.; Yamamoto, H.; Inamori, Y. Intracellular accumulation of phenazine antibiotics produced by an alkalophilic actinomycete. I. Taxonomy, isolation and identification of the phenazine antibiotics. Agric. Biol. Chem. 1988, 52, 301-306.

177. Breitmaier, E.; Hollstein, U. Carbon-13 nuclear magnetic resonance chemical shifts of substituted phenazines. J. Org. Chem. 1976, 41, 2104-2108.

178. Hasegawa, K.; Ueno, Y. The carbon-13 NMR spectra and electronic structure of $3 \mathrm{H}-$ phenoxazin3-ones. Bull. Chem. Soc. 1985, 58, 2832-2839.

179. Maskey, R.P.; Li, F.; Qin, S.; Fiebig, H.H.; Laatsch, H. Chandrananimycins A-C: production of novel anticancer antibiotics from a marine Actinomadura sp. isolate M048 by variation of medium composition and growth conditions. J. Antibiot. 2003, 56, 622-629.

180. Cui, C.B.; Liu, H.B.; Gu, J.Y.; Gu, Q.Q.; Cai, B.; Zhang, D.Y.; Zhu, T.J. Echinosporins as new cell cycle inhibitors and apoptosis inducers from marine-derived Streptomyces albogriseolus. Fitoterapia 2007, 78, 238-240.

181. Sato, T.; Kawamoto, I.; Oka, T.; Okachi, R. A new antibiotic echinosporin (XK-213)-producing organism, isolation and characterization. J. Antibiot. 1982, 35, 266-271.

182. Dübeler, A.; Krastel, P.; Floss, H.G.; Zeeck, A. Biosynthesis of the antibiotic echinosporin by a novel branch of the shikimate pathway. Eur. J. Org. Chem. 2002, 6, 983-987. 
183. Morimoto, M.; Imai, R. Antitumor activity of echinosporin. J. Antibiot. 1985, 38, 490-495.

184. Lee, H.K.; Lee, D.S.; Lim, J.; Kim, J.S.; Im, K.S.; Jung, J.H. Topoisomerase I inhibitors from the Streptomyces sp. strain KM86-9B isolated from a marine sponge. Arch. Pharm. Res. 1998, 21, 729-733.

185. Kamal, N.; Sabaratnam, V.; Abdullah, N.; Ho, A.S.; Teo, S.H.; Lee, H.B. Light-activated cytotoxic compounds from Malaysian microorganisms for photodynamic therapy of cancer. Antonie van Leeuwenhoek 2009, 95, 179-188.

(C) 2009 by the authors; licensee Molecular Diversity Preservation International, Basel, Switzerland. This article is an open-access article distributed under the terms and conditions of the Creative Commons Attribution license (http://creativecommons.org/licenses/by/3.0/). 